\title{
Extensive cross-disciplinary analysis of biological and chemical control of Calanus finmarchicus reproduction during an aldehyde forming diatom bloom in mesocosms
}

Jonasdottir, Sigrun; Dutz, Jörg; Koski, Marja; Yebra, L.; Jakobsen, H.H.; Vidoudez, C.; Pohnert, G.; Nejstgaard, J.C.

Published in:

Marine Biology

Link to article, DOI:

$10.1007 / \mathrm{s} 00227-011-1705-8$

Publication date:

2011

Link back to DTU Orbit

Citation (APA):

Jonasdottir, S., Dutz, J., Koski, M., Yebra, L., Jakobsen, H. H., Vidoudez, C., Pohnert, G., \& Nejstgaard, J. C. (2011). Extensive cross-disciplinary analysis of biological and chemical control of Calanus finmarchicus reproduction during an aldehyde forming diatom bloom in mesocosms. Marine Biology, 158(9), 1943-1963. https://doi.org/10.1007/s00227-011-1705-8

\section{General rights}

Copyright and moral rights for the publications made accessible in the public portal are retained by the authors and/or other copyright owners and it is a condition of accessing publications that users recognise and abide by the legal requirements associated with these rights.

- Users may download and print one copy of any publication from the public portal for the purpose of private study or research.

- You may not further distribute the material or use it for any profit-making activity or commercial gain

- You may freely distribute the URL identifying the publication in the public portal 
Marine Biology Vol. 158, Issue 9, pp 1943-1963 (2011)

http://dx.doi.org/10.1093/plankt/fbt001

Copyright @ Springer, Part of Springer Science+Business Media.
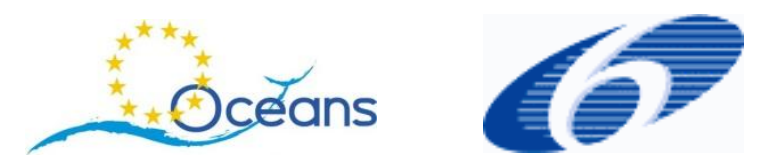

www.eur-oceans.eu
DTU Aqua
National Institute of Aquatic Resources

www.aqua.dtu.dk

\title{
Extensive cross disciplinary analysis of biological and chemical control of Calanus finmarchicus reproduction during an aldehyde forming diatom bloom in mesocosms
}

\author{
Sigrún H. Jónasdóttir ${ }^{1 *}$, Jörg Dutz ${ }^{1}$, Marja Koski ${ }^{1}$, Lidia Yebra ${ }^{2}$, Hans Henrik Jakobsen ${ }^{3}$, Charles \\ Vidoudez $^{4}$, Georg Pohnert ${ }^{4}$, Jens C. Nejstgaard ${ }^{5,6}$ \\ ${ }^{1}$ Technical University of Denmark, National Institute for Aquatic Resources, Kavalergaarden 6, DK-2920 \\ Charlottenlund, Denmark; \\ ${ }^{2}$ Instituto Español de Oceanografía, Centro Oceanográfico de Málaga, Apdo. 285, 29640 Fuengirola, \\ Málaga, Spain; \\ ${ }^{3}$ National Environmental Research Institute, Aarhus University, Box. 358, Frederiksborgvej 399, DK-4000, \\ Roskilde, Denmark; \\ ${ }^{4}$ Friedrich Schiller University, Bioorganic Analytics, Lessingstr. 8, D-07743 Jena, Germany; \\ ${ }^{5}$ Uni Research, Thormøhlensgate 49, 5006 Bergen, Norway; current address: Skidaway Institute of \\ Oceanography, Savannah, GA, USA;
}

\begin{abstract}
Egg and faecal pellet production and egg hatching success of the calanoid copepod Calanus finmarchicus was monitored over a period of 14 days (14-28 April, 2008) while fed water from 4 differently treated mesocosms and ambient water. Two of the mesocosms used were inoculated with the polyunsaturated aldehyde (PUA) producing diatom Skeletonema marinoi while 2 received only nutrient additions with or without silica. The mesocosms developed blooms of $S$. marinoi, mixed diatoms or the haptophyte Phaeocystis pouchetii, respectively. Faecal pellet production of $C$. finmarchicus increased with increasing food availability. Egg production increased with time in all mesocosms to a maximum single female production of 232 eggs female ${ }^{-1}$ day $^{-1}$ (average of 90 eggs female ${ }^{-1} \mathrm{day}^{-1}$ ) and followed the development of ciliates and P. pouchetii, but was not affected by the observed high (up to $15 \mathrm{nmol} \mathrm{L}^{-1}$ ) PUA production potential of the phytoplankton. The hatching success of the eggs produced on the mesocosm diets was high (78-96\%) and was not affected by either aldehydes in the maternal diet or exposure to the dissolved aldehydes in the water.
\end{abstract}

Keywords: Mesocosm, Calanus finmarchicus, egg production, plankton interactions, Skeletonema marinoi *Corresponding author: sjo@aqua.dtu.dk

Article first published online: Sept 2011 


\section{Introduction:}

The effect diatoms have on copepod reproduction, hatching, growth and survival has been a topic of many papers for more than a decade. The studies have generally agreed that pure diatom diets are not always the best food for copepods (Kleppel et al. 1991; Poulet et al. 1994; Ianora et al. 1995; Jónasdóttir and Kiørboe 1996; Ianora et al. 2004). Pure diatom diets are found to have no, some, and up to detrimental effects on egg production rates and especially egg hatching (Ban et al. 1997) and survival of nauplii (Poulet et al. 1994; Koski et al. 2008). The effect can be diatom species specific (Ban et al. 1997) but also strain dependent differences induce different responses in feeding-, egg production, and hatching rates (Ask et al. 2006; Dutz et al. 2008). Different copepod species also react differently in their reproductive output to specific diatom diets (Ianora et al. 2003; Md Amin et al. 2011). Differences in feeding rates can though also be related to the size of the diatom (Rey et al. 2001). The negative effect of diatoms on copepod reproduction and survival has been explained by the differential ability of diatom species/strains to generate polyunsaturated aldehydes (PUA) while mechanically handled by copepods (Miralto et al. 1999; Pohnert et al. 2002; Wichard et al. 2007). Also differential nutritional quality of diatoms (Jónasdóttir and Kiørboe 1996), poor nutrient uptake in the copepod gut due to rapid gut passage time when feeding diatom diets (Dutz et al. 2008) have been brought forward as possible causes for the observed detrimental effects.

Protein, fatty acid, sterol and other biochemical components have been shown to change significantly with the growth stage of diatoms and have, for example, been related to nutrient limitation and light levels (Harrison et al. 1977; Claustre et al. 1989; Jónasdóttir 1994; Brown et al. 1996; Klein Breteler et al. 2005). The production of polyunsaturated aldehydes from some diatoms is also shown to increase with senescing of a culture or a bloom (Ribalet et al. 2007; Vidoudez and Pohnert 2008). Skeletonema marinoi (Sarno and Singone) (previously referred to as S. costatum, Sarno et al. 2005) is one of the diatom species that produces heptadienal, octadienal and octatrienal PUAs upon cell wounding and senescence in high concentrations (Vidoudez and Pohnert 2008). This diatom is a common spring blooming species in the northern waters and occurs naturally in high abundances (over $500 \mu \mathrm{g} \mathrm{C} \mathrm{L}^{-1}$ ) in the Raunefjord and other Norwegian fjords and often dominates the diatom and total algae biomass during the spring bloom (Erga and Heimdal 1984, Erga 1989).

The copepod Calanus finmarchicus (Gunnerus) is one of the most important copepod species in the boreal north-east Atlantic waters where it constitutes up to $70 \%$ of the mesozooplantkon biomass during summer (Fransz et al., 1991). C. finmarchicus ascents as copepodite stage 5 and adult from 
diapause from great depths in the Southern Norwegian Sea (Heath 1999) and starts reproduction before the initiation of the spring bloom (Richardson et al. 1999; Niehoff et al. 1999; Jónasdóttir et al. 2008). However, the major egg production usually occurs during the diatom bloom (Niehoff et al. 1999; Debes et al. 2008). Diatoms are important food items for C. finmarchicus nauplii (Irigoien et al. 2003; Castellani et al. 2008) while the adult females seem to have broader selection of food types. Studies often demonstrate $C$. finmarchicus females having a positive selection for diatoms (Meyer-Harms et al. 1999; Koski and Riser 2006; Koski 2007), but they also select alternative food such as ciliates and larger prey when available (Mayor et al. 2006; Koski 2007). Still, when diatoms are not eaten in proportion to their availability they often can make up a significant part of the diet for $C$. finmarchicus females and late copepodites (Nejstgaard et al. 1997; 2001a, b). Therefore the diatom spring bloom is of importance for initial start of the C. finmarchicus population growth (Debes et al. 2008; Jónasdóttir et al. 2008).

In the present study we used large mesocosms to investigate the biological and chemical effect of PUA producing diatom blooms on C. finmarchicus growth and reproduction. Large mesocosms are an ideal experimental system to investigate the simultaneous chemical and biological effects on plankton communities, including copepods. Such systems allow large volume sampling that is essential for chemical analyses and multiple bottle incubations without greatly affecting the plankton community in the mesocosms. With different manipulation of series of mesocosm bags diverse natural plankton communities can develop in parallel throughout their respective bloom cycles. A number of previous mesocosm studies using similar set-ups at the site of the present study the Raunefjord, the Norwegian National Mesocosm Centre, Espegrend, University of Bergen, have been used to successfully provoke blooms of naturally occurring plankton in near natural conditions (see discussions in Williams and Egge 1998; Nejstgaard et al. 1997, 2006).

The goal of this study was to test if the PUA producing diatom S. marinoi affected the reproductive success, and growth of $C$. finmarchicus over a period of a bloom. S. marinoi/costatum has been a focus of several studies showing that when used as a long term single diet negative effects were observed for Calanus helgolandicus on egg production and hatching (Ban et al. 1997; Ianora et al. 2003). However, no negative effects were observed on $C$. helgolandicus egg production and hatching when S. marinoi was mixed in the diet in a field (Irigoien et al. 2000). C. finmarchicus reproduction was not affected by pure S. marinoi diets (Ban et al. 1997). These differential effects could have been Skeletonema strain dependent. Therefore, the idea with the present study was to use a S. marinoi strain that is known to produce high amounts of polyunsaturated aldehydes. The intent was to closely follow the chemical changes associated with the respective developing blooms 
and to compare it simultaneously with the copepod growth, egg production, hatching success and naupliar survival, in as close as possible natural setting, mesocosms. This would allow us to directly asses the results for effects of specific food composition such as diatom rich diets. The fatty acid content of females and eggs was followed over the mesocosm blooms and those reported in another manuscript along with naupliar survival (Koski et al. unpublished). Due to the vast amount of different chemical and biological measurements conducted on the mesocosm water, this is one of the most extensive studies to date on the biological and chemical control on egg production rates of this species.

\section{Material and Methods}

\section{Mesocosms}

The experiments were conducted over a 14 day period between the $14^{\text {th }}$ and $28^{\text {th }}$ of May 2008 at the Espegrend marine biological field station by Raunefjord, Norway (latitude $60.16^{\circ} \mathrm{N}$; longitude: $5.14^{\circ} \mathrm{E}$ ). On April $14^{\text {th }} 6$ transparent polyethylene enclosures (each $11 \mathrm{~m}^{3}, 2 \mathrm{~m}$ diameter, non covered) were filled with unfiltered sea water from $4 \mathrm{~m}$ depth just outside the mesocosms, and the following day April $15^{\text {th }}$ (day 1) the mesocosms received different treatments. In the present study we sampled 4 of those mesocosms, labelled B, C, E and F. All mesocosms were fertilized with 0.4 $\mu \mathrm{mol} \mathrm{L}{ }^{-1}$ phosphate and $4.24 \mu \mathrm{mol} \mathrm{L}^{-1}$ nitrate. Mesocosm B had no more treatment, mesocosm C, E and $\mathrm{F}$ had additional $3.61 \mu \mathrm{mol} \mathrm{L} \mathrm{L}^{-1}$ silicate fertilization and mesocosms $\mathrm{E}$ and $\mathrm{F}$ were inoculated with cultured Skeletonema marinoi (Strain G4, University of Bergen) corresponding to an increase of the low in situ concentrations with ca. 400 and 1000 cells $\mathrm{mL}^{-1}$ respectively (Table 1). Water temperature was measured daily throughout the water column in the mesocosms with a SAIV SD204 CTD.

Water was sampled from each of the mesocosms every morning. The water was immediately brought to the laboratory in 5 and $20 \mathrm{~L}$ carboys where filtrations and incubations took place.

\section{Chlorophyll filtration, extraction and analysis}

Chlorophyll $a$ ( $\mathrm{Chl} a$ ) concentrations were determined daily in the mesocosm bags by filtering duplicate water samples onto 0.2- $\mu \mathrm{m}$ Gelman $47 \mathrm{~mm}$ diameter polycarbonate filters, and a single serial fractionation series onto 10, 5, 1 and $0.2 \mu \mathrm{m}$ Gelman $47 \mathrm{~mm}$ diameter polycarbonate filters. The filters were extracted immediately in $90 \%$ acetone overnight at $4{ }^{\circ} \mathrm{C}$ and analyzed using a Turner Designs 10-AU fluorometer (Turner Designs, Sunnyvale, CA, USA).

\section{Protist plankton}


Protists were counted in vivo by a Cytobuoy ${ }^{\mathrm{TM}}$ scanning flowcytometer (CytoBuoy b.v. Woerden, The Netherlands) and by a FlowCAM II ${ }^{\mathrm{TM}}$ (Fluid Imaging Technologies, Yarmouth, ME USA) fitted with black and white camera. S. marinoi were counted in triplicates by the Cytobuoy flowcytometer following the procedures outlined by Takabayashi et al. (2006). The flowcytometer was unable to identify the colonial form of Phaeocystis pouchetii so cell concentrations were counted on colony images of the FlowCAM. The FlowCAM was set in auto-image mode using a $4 \mathrm{X}$ objective and a total sample volume of ca $4.2 \mathrm{~mL}$ (run time $20 \mathrm{~min}$ ) were analysed daily from each mesocosm. Each sample was fed the FlowCAM through a vertical tube from a beaker mounted above the vertical mounted flow-cell, in a fashion that prevented particle sedimentation in the flow system. The sample was stirred by a small lab stirrer set at the lowest speed (ca $5 \mathrm{rpm}$ ). The dimension of the flow cell, determined by the objective was $2 \mathrm{~mm} \times 0.1 \mathrm{~mm}(10 \mathrm{X})$ (Vitrocom, Mountain Lakes, NJ, USA). Phaeocystis colonies were counted and the numbers of cells were estimated by use of a calibrated regression between manually counted number of colonial cells per colony and colony grey scale area of FlowCAM images. Major protozoan groups $>15 \mu \mathrm{m}$ were enumerated by the FlowCAM. Images were manually sorted into species classes such as ciliates and major heterotrophic dinoflagellates. The biomass of the individual groups such as dinoflagellates, ciliates, and total were converted to carbon biomass using the generic carbon-to-volume relationship given by Menden-Deuer and Lessard (2000).

\section{Filtration for lipids and PUA and chemical analyses}

For PUA sampling and analysis, see Vidoudez et al. (2011b). For the determination of the fatty acid and sterol profile of the plankton, 0.5-5 L were filtered on GF/C filters under moderate vacuum. The filters were transferred into $4 \mathrm{~mL}$ brown glass vials and covered with $1 \mathrm{~mL}$ of methanol and 2 $\mu \mathrm{L}$ of internal standard (myristic acid-d27; Sigma-Aldrich, Deisenhofen, Germany), $10 \mathrm{mg} \mathrm{mL}^{-1}$ in methanol) and the samples were kept at $-20^{\circ} \mathrm{C}$ until the end of the experiment. The samples were transported frozen and stored there at $-80^{\circ} \mathrm{C}$ until analysis. The fatty acid and sterol profiles were determined simultaneously by gas chromatography-mass spectrometer (GC-MS) after transesterification (modified from Lepage and Roy, 1984) and silylation: samples were cooled to 77 $\mathrm{K}$ in a liquid nitrogen bath prior freeze-drying. Five hundred $\mu \mathrm{L}$ of methanol:acetyl chloride 9:1 (> 99.0\%, Sigma-Aldrich), $300 \mu \mathrm{L}$ of hexane, and two glass beads were added to the freeze-dried samples before tightly closing the vials. Samples were sonicated in an ultrasound bath for $10 \mathrm{~min}$ before vortexing for $1 \mathrm{~min}$ and subsequently incubated at $100^{\circ} \mathrm{C}$ for $10 \mathrm{~min}$. Samples were cooled on an ice bath and $1 \mathrm{~mL}$ of deionised water was added and the samples were vortexed for another minute. Phase separation was achieved by centrifugation. The hexane phase was then transferred into $1.5 \mathrm{~mL}$ glass vials (Macherey-Nagel, Düren, Germany). Five hundred $\mu \mathrm{L}$ of chloroform were 
then added to the remaining aqueous sample and the vials were vortexed for $5 \mathrm{~min}$. After centrifugation, the chloroform phase was combined with the hexane phase. One mL of chloroform was then added to the samples and the vortex-centrifugation cycle was repeated as described above. The combined organic phases were dried over anhydrous sodium sulphate and the supernatant was removed from the drying agent by pipetting. The solvent was evaporated under vacuum and the samples were re-suspended in $100 \mu \mathrm{L}$ of hexane-chloroform (1:1). After transfer into $200 \mu \mathrm{L}$ glass inserts (Macherey-Nagel, Düren, Germany), $50 \mu \mathrm{L}$ of N-nethyl-N-(trimethylsilyl)trifluoroacetamide (Macherey-Nagel, Düren, Germany) was added, the vials were closed with caps fitted with PTFEbutyl-PTFE septa and incubated at $60^{\circ} \mathrm{C}$ for $20 \mathrm{~min}$ to allow derivatisation of the sterols. The samples were then stored at $-80^{\circ} \mathrm{C}$ until analyses by GC-MS. A GCT premier time-of-flight mass spectrometer (Waters, Manchester, UK) coupled with an Agilent 6890N gas chromatograph equipped with a DB-5ms $30 \mathrm{~m}$ column $(0.25 \mathrm{~mm}$ internal diameter, $0.25 \mu \mathrm{m}$ film thickness, with 10 m Duraguard pre-column, Agilent, Waldbronn, Germany) was used with the following parameters: GC program: $60^{\circ} \mathrm{C}$ for $5 \mathrm{~min}$, then ramping to $300^{\circ} \mathrm{C}$ at $10^{\circ} \mathrm{C} \mathrm{min}^{-1}$. This last temperature was held for $10 \mathrm{~min}$. The injector, transfer line and ion source temperature was set to $300^{\circ} \mathrm{C}$. Electron Impact ionisation (EI $70 \mathrm{eV}$ ) was used. The samples were injected in Split 1-15 depending on the concentration. Fatty acid and sterols were identified by comparison of the retention times and mass spectra with authentic standards. The PUA analysed include 2,4-heptadienal, 2,4-octadienal, 2,4,7octatrienal, 2,4-decadienal and 2,4,7-decatrienal (these metabolites will be referred to in the following by their names not including the numbering of the double bonds). Quantification of fatty acids, sterols and PUA was validated using established analytical criteria (data not shown).

\section{Egg production}

\section{Sampling of copepods}

Calanus finmarchicus for incubations were sampled from a station in the Raunefjord 0.5 nautical miles North West of the field station, by using a WP-2 net with a $200 \mu \mathrm{m}$ mesh size and a nonfiltering cod end, hauled obliquely from ca $20-\mathrm{m}$ to the surface at ca $0.5 \mathrm{~m} \mathrm{~s}^{-1}$. Several tows were taken to obtain sufficient number of individuals. On deck, the content of the cod end was immediately diluted with ambient water and the sample was brought back in thermo boxes to the laboratory within 2 hours from the first net tow, and was kept cool with cooling elements. All handling of copepods, incubations and counting of eggs and faecal pellets was carried out in a dim lighted $7^{\circ} \mathrm{C}$ temperature controlled walk-in room. At day 7 the temperature in the mesocosms had increased to $8^{\circ} \mathrm{C}$ and the temperature the walk-in room was changed accordingly to $7.5^{\circ} \mathrm{C}$.

Photoperiod in the walk-in room was kept at 16:8 h, dim light: dark, and all incubations described below were covered. 
216 Egg production experiments

217 Incubations started on day 2 after the inoculation of the mesocosms, with first results on day 3. For 218 the egg production experiments, 20 replicates of $600 \mathrm{ml}$ beakers were set up for each mesocosm 219 treatment and an additional natural seawater control with water from outside the mesocosms. Each 220 beaker contained a Plexiglas insert with a $300 \mu \mathrm{m}$ false bottom mesh which kept the female away 221 from her eggs and faecal pellets that in turn passed the mesh and remained on the bottom of the 222 beaker. One C. finmarchicus female was placed in each of the beaker inserts. Initially, the filtered 223 seawater control was set up with 8 replicate females (as above). These controls were run for only 5 224 days. On day 6, new controls were set up with 10 new females and ambient water and run for the 225 remaining experimental period. These new females came from the net tow sampled at day 1 and 226 had received ambient food (replaced daily), but their egg production had not been monitored prior 227 to day 5. Each day females were transferred to a new food suspension from the newly sampled 228 mesocosms and ambient sea water. Eggs and faecal pellets were concentrated on a 50 $\mu m$ sieve and 229 gently flushed into a small Petri dish and immediately counted. Every other day the Petri dish 230 containing eggs were set aside for 3 days allowing the eggs to hatch, after which the nauplii and 231 remaining eggs were counted. The other days eggs were sampled for lipid analyses (Koski et al. 232 unpublished). Daily, $500 \mathrm{ml}$ of water from each mesocosm were filtered through $50 \mu \mathrm{m}$ sieve to 233 account for background eggs and faecal pellets.

\section{Faecal pellet measurements and calculations}

Faecal pellets were sampled every other day after counting and fixed in $4 \%$ formalin for later size measurements. Pellets were measured by using an inverted microscope at $100 \mathrm{x}$ magnification.

\section{Statistics}

242 Comparisons between mesocosms were done with One-way ANOVA, but with Kruskal Wallis 243 ANOVA on Ranks if data could not be normalized. General Linear Method 2-way ANOVA was 244 used to compare faecal pellet sizes. Holm-Sidak or Dunn's post hoc pair-wise comparisons were 245 carried out when the ANOVAs gave significant differences. Data reduction was conducted on fatty 246 acid, sterol, microplankton and chlorophyll by use of principle component analysis (PCA). A proxy 247 variable, representing the group of significantly correlated variables on each different principle 248 components, was tested against egg production, faecal pellet production and hatching success using 249 stepwise multiple regression analysis. Hatching values were arcsine transformed and egg and faecal 
pellet production data were square-root transformed, to meet normality and equal variance requirements. The statistical packages Sigma Stat and PASW were used for the analyses.

\section{Results}

Mesocosm development, chlorophyll a, phyto- and microplankton

The temperature increased in the mesocosms and in the ambient water from $6.3^{\circ} \mathrm{C}$ on the first day to $8.7^{\circ} \mathrm{C}$ at the last day (data not shown). The temperature of the incubations was kept constant at $7{ }^{\circ} \mathrm{C}$ for the first 6 days and increased to $7.5^{\circ} \mathrm{C}$ at day 7 till the end of the experiment. The temperature change in the mesocosms did therefore not transfer to the incubations.

The total Chl $a$ concentrations showed that all manipulated mesocosms developed phytoplankton blooms, while the ambient water remained at low post-bloom concentrations throughout the experimental period (Fig. 1a). An un-manipulated mesocosm, mesocosm A, not presented in this study, developed the same way as the ambient outside the mesocosms indicating that the mesocosms enclosement did not generate artificial growth conditions (H.H. Jakobsen, J.C. Nejstgaard and G. Pohnert pers. com). Mesocosm F inoculated with the highest amount of Skeletonema marinoi both reached the highest total $\mathrm{Chl} a$ concentration and culminated at day 7 , one day before all other mesocosms. Mesocosm B and C showed a less pronounced peak with the largest fraction of the Chl $a(>10 \mu \mathrm{m})$ culminating around day 12 (Fig. 1b). Mesocosm E inoculated with a lower amount of $S$. marinoi showed an intermediate development in Chl $a$. S. marinoi were a major component of the phytoplankton in both mesocosms E and F, and reached peak concentrations of 133 and $480 \mu g \mathrm{C} \mathrm{L}^{-1}$, respectively (Fig. 2a). S. marinoi were also detected in the other mesocosms (B and $\mathrm{C}$ ) but at extreme low concentrations $\left(<6 \mu \mathrm{gC} \mathrm{L}^{-1}\right)$. Colonies of Phaeocystis pouchetii (Hariot) Lagerheim followed the decline of the S. marinoi bloom in mesocosms E with maximum concentrations ranging between 400 and $670 \mu \mathrm{gC} \mathrm{L}^{-1}$ and coinsisted with the $S$. marinoi bloom in mesocosms F maintaining concentrations about $300 \mu g C \mathrm{~L}^{-1}$ during days 8-10. In mesocosms B and C P. pouchetii colonies were the dominant phytoplankton biomass $>15 \mu \mathrm{m}$ (peak 1300 and $1200 \mu g \mathrm{~L} \mathrm{~L}^{-1}$ respectively, Fig. 2). Heterotrophic dinoflagellates (sum of Gyrodinium spirale (Bergh) Kofoid and Swezy, G. dominans Hulbert and Protoperidinium bipes Poulsen) were found in similar concentrations in all mesocosms (100-150 $\mu \mathrm{gC} \mathrm{L}^{-1}$; Fig. 2a). While the concentrations of ciliates were below $100 \mu \mathrm{gC} \mathrm{L}^{-1}$ in both the ambient water and the mesocosm $\mathrm{B}$, the ciliates reached higher concentrations in mesocosms with S. marinoi (C, E, F), with the

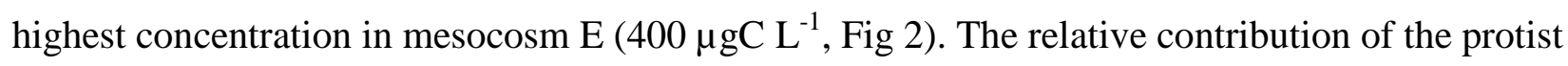
types from day 4 and onward is presented in Fig. 2 b. 
$286 \quad$ Fatty acids

287 The polyunsaturated fatty acids (PUFA) in mesocosms B and C were dominated by 18:3(n-6) and 288 22:6(n-3) (Table 2). In mesocosm $C$ that had received the additional Si addition the fatty acid 289 16:1(n-7) which is typical for diatoms could be detected in higher amounts than in mesocosm B. 290 Algae from mesocosm $\mathrm{E}$ and $\mathrm{F}$ had considerably higher proportion of 16:1(n-7) and 20:5(n-3) than 291 those of mesocosms B and C. High levels of 22:6(n-3) were also detected in these mesocosms but 292 highest in mesocosm F (Table 2). The monounsaturated fatty acids (MUFA) and PUFA followed 293 the same pattern as the bloom development (Fig. 3).

\section{$\underline{\text { Sterols }}$}

The main particulate sterols were cholesterol, brassicasterol and sitosterol (Fig. 3). The sterol content (total sterol) was significantly correlated with $P$. pouchetii $\left(\mathrm{R}^{2}=0.65, \mathrm{p}<0.001\right)$. In mesocosm F particularly high concentrations of cholesterol were detected.

\section{$\underline{\text { PUA }}$}

301 The dynamics of the polyunsaturated aldehydes is described elsewhere (Vidoudez et al. 2011). Heptadienal and octadienal production was correlated to S. marinoi only, while decadienal concentration where correlated to the combined densities of P. pouchetii and S. marinoi.

\section{Data reduction}

306 Data reduction (PCA) sorted the food environment into 4 major components that explained $87 \%$ of the variance of the variables in the analysis (Table 3). Component 1 was composed of the introduced diatom S. marinoi, hepta-, octa- and decadienal and Chl $a>10 \mu \mathrm{m}$, and to a lesser degree cholesterol and monounsaturated fatty acids (MUFA). The second component was composed of $P$. pouchetii, the brassica-, campe- and sitosterols. The third component was based on the ciliates, the

312 Component 4 was composed of the PUFAs 22:6(n-3), 18:3(n-3) and 18:3(n-6) and to a lesser degree $31320: 5(n-3)$.

\section{Egg production}

316 After initial drop from the first to the second day of incubation (between days 3 and 4) average egg 317 production rates (EPR: eggs female ${ }^{-1} \mathrm{day}^{-1}$ ) in all mesocosms increased gradually with time form ca 31810 eggs female ${ }^{-1}$ day $^{-1}$ till ca 80 eggs female ${ }^{-1}$ day $^{-1}$ in the end of the experiment (Fig. 4a). EPR in 319 filtered seawater (FSW) dropped to 0 at the third measurement (day 5) while in the ambient 
seawater (day 7-14) the average EPR measured $12 \pm 7$ eggs female $^{-1} \mathrm{~d}^{-1}( \pm \mathrm{SE})$ and did not change significantly over time (Kruskal Wallis one-way ANOVA, $\mathrm{H}_{6}=7.1, \mathrm{p}=0.314$ ). There were no significant differences in egg production rates between mesocosms when compared over the whole period (days 5-14), but the egg production rates at the final day (day 14) differed significantly between the ambient water and each of the mesocosms C, E and F ( $p<0.05$, Dunn's post hoc comparison).

The maximum daily egg number was highest (232 eggs) for a female incubated in mesocosm $\mathrm{E}$ water, but similarly high maximum numbers were was also in the other mesocosm treatments (167, 173 and 202 eggs from water from mesocosm F, B and C respectively, Table 1).

The fraction of spawning females increased with time (Fig. 4b) but was significantly lower in the ambient food treatment compared to all the mesocosm treatments (Holm-Sidak post hoc comparison of means, $\mathrm{p}>0.05$ ). Additionally, there was a significant difference between the fraction of females producing eggs in waters from mesocosm B and C (Holm-Sidak post hoc comparison of means, p > $0.05)$.

The cumulative egg production was highest in the treatment with water from mesocosm $\mathrm{F}$ but lowest and almost half the value in the treatment from mesocosm B (Table 1). Female mortality was highest in the incubations from mesocosms B and E (35 and 40\% respectively). No female died after the 12 day incubations from mesocosm $\mathrm{F}$, which also had highest percent of producing females (88\%, Table 1). The cumulative egg production does not correct for loss of females in the incubations as time went on, and reflects therefore the potential production of a population receiving the different treatments.

Due to the observed 2 day adjustment in EPR to the food availability (Fig. 4a), stepwise multiple regression was run on EPR excluding the EPR on the first 2 days of the experiment (days 3 and 4) and excluding the FSW treatment. Hence, due to this 2 day delay in EPR in response to the food environment, all correlations were done on the food available 2 days earlier. The environmental variables used in the analysis were based on the PCA data reduction, but using the measures of $S$. marinoi as a representative for the highly correlated variables on principal component (PC) $1, P$. pouchetii for PC2, ciliates for PC3 and 22:6(n-3) for PC4. Additionally the variables that had lower but significant loading on the different PCs were added separately to the regression analyses. These were cholesterol (for MUFA on PC1), G. dominans (PC3) and 20:5(n-3) (PC4, but also high on PC3; Table 3). Egg production rates of C. finmarchicus were best explained by the 22:6(n-3) fatty 
acid (51\% of the total variation in EPR explained) but the combination of the protoplankton types $P$. pouchetii and ciliates contributed additional $27 \%$ to the model explanation. Finally by adding $S$. marinoi to the model improvement the explanation power by extra 3\% (Stepwise Multiple Regression, $\mathrm{R}^{2}=0.81, \mathrm{~F}_{4}=41.7, \mathrm{p}<0.001$, Table 4, Fig. 5). To further investigate the effects of specific food types and PUA on the observed egg production rates we used the method described in detail in Irigoien et al. (2005) based on the mixing model by Jónasdóttir et al. (1998). The relation between the residuals of the regression between EPR and total protist carbon (shown in Fig 5e) were tested against the fraction of relative abundance of S. marinoi and P. pochetii in the food environment (Fig. 6a, b). The regressions were not significant which means that none of these food types were specifically important for $C$. finmarchicus egg production rates. The same was apparent with the relative abundance of ciliates $\left(\mathrm{R}^{2}=0.00 ; \mathrm{P}=0.87\right)$ and dinoflagellates $\left(\mathrm{R}^{2}=0.02 ; \mathrm{P}=0.32\right.$; plots not shown). Similarly, no negative effects were apparent when the concentration of dissolved and particulate PUA were related to the residuals of EPR (Fig. 6c,d) $\left(\mathrm{R}^{2}=0.00\right.$ and $\mathrm{R}^{2}=0.00 \quad ; \mathrm{P}=$ 0.87 and $\mathrm{P}=0.87$ respectively).

\section{Hatching}

Hatching success of eggs increased from ca $60 \%$ on day one (where eggs made from diet previous to the incubations) to 83-89\% hatching (Fig. 4c, Table 1). No difference was found in hatching success between any of the mesocosm treatments (Kruskal Wallis ANOVA on arcsine transformed hatching data: $\mathrm{H}_{4}=4.5, \mathrm{p}=0.35$ ) when day 1 is excluded, and no significant difference within the treatments during the incubations. Koski et al. (unpublished) presents in further details the hatching and the eggs and naupliar development in the present study.

\section{Faecal pellet production}

Number of faecal pellets produced per female per day (Table 1) differed significantly between the mesocosm treatments (One way ANOVA, $\mathrm{F}_{4}=6.97, \mathrm{p}<0.001$ ). Significant differences were observed between pellet production of copepods feeding on water from mesocosm $\mathrm{C}$ produced significantly more faecal pellets compared to copepods feeding on mesocosm B. The copepods in mesocosm C, E and F produced significantly higher number of pellets compared to the copepods feeding in the ambient water treatment (Holm-Sidak post hoc comparisons at $\mathrm{p}=0.05$ ). In all but the ambient water the faecal pellet production increased for the first 7-11 days after which the production decreased again.

Faecal pellet length and consequently their volume (Fig. 4d) increased significantly with time in all mesocosm treatments (linear regression for all mesocosms $\mathrm{p}<0.001$ with $\mathrm{R}^{2}=0.54,0.51,0.19$ and 
0.12 for mesocosms B, C, E and F, respectively on volume, data not shown). There was a significant difference in faecal pellet volume size between the mesocosms, where pellets from mesocosm B were significantly larger than the pellets from all the other mesocosms (Holm Sidak post hoc pairwise comparison $\mathrm{p}=0.05)$.

Faecal pellet production rate as faecal volume (FPR: $\mu \mathrm{m}^{3}$ female $^{-1}$ day $^{-1}$ ) of $C$. finmarchicus were best explained with the combination of the concentrations of ciliates and P. pouchetii, and to a lesser degree the 22:6(n-3) fatty acid (Stepwise Multiple Regression $R^{2}=0.71, F_{3}=44.0, p<0.001$, Table 4). The model included the Chl $a$ in the size fraction 5-10 $\mu$ m as more realistic representative of PC 1 for faecal pellet production than cholesterol. The individual correlations are demonstrated in Fig. 7.

There was a significant positive relationship between FPR and egg production rates $\left(\mathrm{R}^{2}=0.79\right.$; $\mathrm{p}>$ Fig. 8).

\section{Discussion/Conclusion}

406 The development of the plankton communities in the 4 mesocosms and the ambient water were well suited for a comparative study as it generated a wide variety of food types and chemical compositions at broad concentration ranges. There were mainly 2 types of systems developing, one dominated with Phaeocystis pouchetii, the fatty acids 18:3(n-6) and 22:6(n-3) and cholesterol, and medium levels of decadienal and low levels of heptadienal, and the other with Skeletonema marinoi, the fatty acids 16:1(n-7), 20:5(n-3) and 22:6(n-3) increasing with time and high levels of hepta- and decadienal PUAs. Ciliates and heterotrophic dinoflagellates increased with time and peaked at

From day 7 and onwards in mesocosms F and from day 9 and 10 the mesocosms B, C and E, food availability was very abundant (> $800 \mu \mathrm{g} \mathrm{C} \mathrm{L}^{-1}$, Fig. 2); a concentration by which Calanus finmarchicus should not have experienced food limitation (Båmsted et al. 1999). The maximum faecal pellet production rate was achieved between 600-1000 $\mathrm{ggC} \mathrm{L}^{-1}$ (Fig 7e), while maximum egg production was achieved between 400 and $700 \mu \mathrm{gC} \mathrm{L}^{-1}$ (Fig. 5e). Similar egg production in all mesocosms (B-F) could imply that individual food types dominating the different mesocosms (Fig.

2) were not important in the determination of reproductive success. However, copepods do not necessarily have fed on them in proportion. According to the optimal foraging theory $C$. finmarchicus could have allowed itself to be selective with the high concentration of mixed diet available (Fig. 2) and avoid the least favourable food items. Based on the high PUA content of $S$. 
marinoi (1.2 - 4.2 fmol cell $^{-1}$, Ribalet et al. 2007) we could expect avoidance of this potentially harmful diatom. There are, however, several indicators that $C$. finmarchicus in our study did not specifically avoid S. marinoi. The only direct measure of ingestion is from the parallel study of Barofsky et al. (2010) that report that ingestion of S. marinoi was highest 1-3 days after the peak of the S. marinoi blooms in mesocosm $\mathrm{E}$ and $\mathrm{F}$ (their mesocosm 1 and 2 respectively; measured every other day). This is during the decline of the bloom when PUAs were expected to be at its highest according to the study of Ribalet et al. (2007). The second indication of $C$. finmarchicus actively feeding on S. marinoi is based on fatty acid composition of the females (presented in Koski et al. unpublished). The diatom fatty acid 16:1(n-7) was found in significantly higher concentrations in females from the S. marinoi impregnated mesocosms E and F compared to mesocosms B and C. Koski et al. (unpublished) additionally show that the fatty acids in the eggs did not differ from seston fatty acids, which indicates no selective feeding, and no selective control of fatty acids from females to the eggs. Therefore, even though we cannot state that no selection took place we can say with certainty that $C$. finmarchicus did not avoid eating $S$. marinoi.

Faecal pellet volume production (FPR) is a good indicator of Calanus feeding (e.g. Nejstgaard et al. 2001b). The faecel pellet production was high (30-40 pellets female $\mathrm{d}^{-1}$ ) and similar in most mesocosms (Table 1) and comparable to e.g. measurements conducted by Rey et al. (1999) on $C$. finmarchicus. In our study FPR (volume based) was highest in mesocosms E, F and C where Phaeocystis was abundant, but FPR was lower in mesocosms B (Fig. 4d, Table 1) where there was less food diversity, and P. pouchetii dominated most of the period with 85-95 \% of the biomass. Faecal pellet production is also dependent on the diet type (Besiktepe and Dam 2002, Dutz et al. 2008), but in the present study it followed food abundance fairly well up to approximately 1000 $\mathrm{gg}$ $\mathrm{C}^{-1}$ (Fig7e). On the whole (all mesocosms) the pellet production was best explained with $P$. pouchetii, the PUFA proxy (22:6(n-3)) and ciliate concentrations but not $S$. marinoi (Table 4). However, as argued above and by the study of Barofsky et al. (2010) it does not imply that $C$. finmarchicus did not eat $S$. marinoi. Our measures also show that the pellet production in the water from these $S$. marinoi inoculated mesocosms was highest one or two days after the peaks of the relevant bloom (Fig. 4d). The peak of the particulate PUA coincided with the $S$. marinoi peaks and lasted couple of days after the blooms. Therefore, ingestion of potentially deterrent PUA was thus during and right after the peak of the bloom, when Barofsky et al. (2010) recorded the main feeding on S. marinoi. The decrease in faecal pellet production was directly related to decrease in the food availability and coincides with the carbon concentration of protoplankton ( $P$. pouchetii, dinoflagellates and ciliates, Table 4). 
The egg production rate of Calanus finmarchicus was relatively high in most of mesocosms, both in the beginning and the end of our study. We measured one of the highest egg number ever recorded of a single female over $24 \mathrm{hr}$ period for this species: 200 and 230 eggs for individual females in mesocosms C and E (for comparison see overview in Jónasdóttir et al. 2005, 2008). Even though we compared the EPR with food condition 2 days earlier, and therefore did not use the 2 last days of the experiment in the analyses, the rise, peak and the fall of both $P$. pouchetii and the $S$. marinoi blooms were included in the diet for C. finmarchicus in the analyses (Fig. 2). Food availability was the main determinant for the observed EPR as strongly indicated by the close correlation between FPR and EPR (Fig. 8) and the highly significant correlation between protist carbon and EPR (Fig 5e). The increase in spawning frequency (Fig. 4b) also follows the food availability. This correlation is based on a combination of different food types that build up the best explainable model for the variation in the egg production rate. Total protist carbon explained $71 \%$ of the variation in EPR (non linear model; Fig 5e). A more detailed analysis of the specific food environment including food quality indicators (PUFA and sterols) could however, explain 81\% of the variation in the linear stepwise multiple regression model. The breakdown of the analysis revealed that seston PUFA (22:6(n-3)) and $P$. pouchetii together explained $71 \%$ of the variation in the observed EPR. Ciliates (as a proxy for flagellates, Gyrodinium spirale and Protoperidinium bipebs) and Skeletonema (as proxy for octa-, deca-, and heptadienal) made up the rest leaving only $19 \%$ of the variation unexplained. Interestingly, S. marinoi and accordingly the potentially detrimental PUAs had positive, rather than negative effect on the EPR, in contrast to what was expected.

The source of the PUFAs in the mesocosms is a combination from the diatoms high in the fatty acid 20:5(n-3) (Viso and Marty 1993) and dinoflagellates that are high in C18 and 22:6(n-3) PUFAs (e.g. Jónasdóttir 1994). P. pouchetii does on the other hand contain very low levels of PUFA (Nichols et al. 1991), but may be rich in camper-, brassica- and sitosterols as they were highly correlated with $P$. pouchetii in the present experiment (Table 3). PUFAs and sterols have been shown to be essential for copepod egg production and growth (e.g. Jónasdóttir and Kiørboe 1996; Hassett 2004; Klein Breteler, 2005), but do not seem to have been limiting the EPR in the present study. The different protist types therefore, seem to have complemented each other to generate ideal food condition for $C$. finmarchicus during the experiment.

The only difference in the reproduction between mesocosms observed in this study was in the fraction of spawning females in mesocosms B and C (Fig 4b, Table 1). EPR in mesocosms B water was also lower than in mesocosms $\mathrm{C}$ although the difference was not significant. We cannot explain 
the difference in the spawning performance by the quality of the seston measured as polyunsaturated fatty acids normalized to carbon, but a significant positive correlation with low regression fit was found between seston cholesterol (carbon normalized) in mesocosms B and C and the fraction of spawning females (arcsine transformed, $\mathrm{R}^{2}=0.17, \mathrm{p}=0.049, \mathrm{n}=18$ ). However, this relationship did not hold when all mesocosms were included in the analysis. The best relationship in spawning performance including all mesocosms and ambient water was with carbon content of the seston $\left(\mathrm{R}^{2}=0.49, \mathrm{p}<0.001, \mathrm{n}=55\right.$; data not shown). In any case, on the final day of the experiment there were no differences in the spawning performance of the females feeding on the different mesocosm water.

In this and most studies the PUA concentrations documented are the potential concentrations, i.e. the concentration that could be released from the algae, when wounded either when eaten or during senescence. The parameter dissolved PUA represents concentration of these metabolites in the water and thus the concentrations copepods and their eggs are exposed to. In addition to the PUA transferred through the diet of the female these dissolved PUA have the potential to directly affect hatching and naupliar survival. There are many studies that demonstrate inhibition of egg, embryo and naupliar development by direct exposure to dissolved PUA. Most of the studies that give PUA concentrations or enough information to calculate the PUA concentrations are summarised in Table 5. Most reports of detrimental effects of PUA are found with the commercially available aldehyde decadienal, and inhibition of copepod egg hatching, cell division of embryos and starfish sperm motility were found at direct exposure at concentrations between 3,300-10,000 nmol L-1 of dissolved decadienal. Studies on the effects of post ingestion of PUA producing diatoms (maternal effects) have given more variable results; from no effects to poor hatching and/or naupliar survival (see Table 5). Therefore the question arises if the PUA concentration in our mesocosm experiment was just too low to cause failure in hatching and development. The potential PUA concentration (bound in phytoplankton) in this study was between 0 - $17 \mathrm{nmol} \mathrm{L}^{-1}$ where the dissolved PUA was somewhat lower (0 - $4.9 \mathrm{nM})$. These concentrations are orders of magnitude lower than those used in the laboratory studies that demonstrate detrimental damage on eggs and nauplii (Table 5).

While there are remarkably few records of natural concentrations of PUA - particulate or dissolved, the few available studies show very similar concentrations as we measured in our mesocosms (0 28 nmol L ${ }^{-1}$ particulate PUA and 0 - 0.1 nM dissolved PUA, see Table 5). Our particulate concentrations are therefore close to the highest reported concentrations in the Adriatic Sea (28 nmol L ${ }^{-1}$ ) with no apparent effect on the eggs and egg production. The dissolved fraction in the mesocosms was however 50 times higher than the ones measured at the same station as the high 
particulate PUA in the Adriatic (Table 5) but still with no measurable effect on the egg hatching. The comparison summarised in Table 5 shows that most studies reporting detrimental effects of dissolved aldehydes used concentrations 2 to 7 orders of magnitude higher than ever measured in the natural environment and are therefore not useful, if not directly misleading for our understanding of how the chemical and biological environment affects impact copepod reproduction and growth. Those studies only demonstrate that the most active PUA, decadienal does not have any effect on egg hatching and naupliar development at highest natural concentrations and the natural dissolved concentrations can well increase over 1000 fold before they directly affect egg and naupliar development. Indeed, Wichard et al. (2007) who determined particulate PUA in the field did not find any correlation to the copepod egg production hatching or naupliar abnormality. Similarly, in a laboratory study Dutz et al. (2008) demonstrated that PUA was not the determining factor in hatching failure of the copepod eggs using potential concentrations 2100 times higher than the highest potential natural concentrations and ingestion rates of PUA of 0.1 nmol female $\mathrm{e}^{-1} \mathrm{~d}^{-1}$. Therefore presence of potentially PUA producing diatoms does not seem to be the exclusive factor controlling reproductive success of copepods in nature.

In summary, this study shows that $C$. finmarchicus egg production depends primarily on food availability as a combination of ciliate, $P$. pouchetii and the availability of the essential PUFAs representing range of diets of complimenting nutritional quality. Egg quality was high on the mesocosm diets and was not inhibited by any means. This study further demonstrates that one of the highest measured natural PUA concentrations both as potential PUA and dissolved PUA, associated with $S$. marinoi blooms did not affect $C$. finmarchicus reproduction success.

\section{Acknowledgements:}

We thank the European FP6 Project "EUR-OCEANS" for granting funds to the project "Research integration by sharing facilities and cooperative development of new approaches: What does it take to create specific diatom blooms and quantify the effects on pelagic ecosystems in mesocosms?” with lead PI: JC Nejstgaard. A comprehensive mesocosm experiment can only be conducted by a substantial team of scientists, we therefore thank our colleagues A Barofsky, B Diekmann, A Spielmeyer, I Pesmatzoglou, Y Carotenuto, A Gerecht, A Ianora, C Augustin, P Simonelli, C Troedsson, A Calbet, R Amin, U Båmstedt, J Bergkvist, C Stangenberg, S-Å Wängberg, for various participation in running the mesocosm experiment. We thank D Evensen, University of Bergen for providing phytoplankton cultures. CV and GP thank the German Research Foundation (PO 628/51), the SNF and the Volkswagen Foundation for funding. JCN was supported by the Norwegian 
565 Research Council (NRC) project 152714/120 30. LY was partially supported by a EUR-OCEANS 566 Mobility grant.

567 


\section{References}

Adolph S, Bach S, Blondel M, Cueff A, Moreau M, Pohnert G, Poulet S, Wichard T, Zuccaro A (2004) Cytotoxicity of diatom-derived oxylipins in organisms belonging to different phyla. J Exp Biol 207:2935-2946

Ask J, Reinikainen M, Båmstedt U (2006) Variation in hatching success and egg production of Eurytemora affinis (Calanoida, Copepoda) from the Gulf of Bothnia, Baltic Sea, in relation to abundance and clonal differences of diatoms. J Plankton Res 28: 683-694

Båmstedt U, Nejstgaard JC, Solberg PT (1999) Utilisation of small-sized food algae by Calanus finmarchicus (Copepods, Calanoida) and the significance of feeding history. Sarsia 84:19-38

Ban S, Burns C, Castel J, Chaudron Y, Christou E, Escribano R, Umani S, Gasparini S, GuerroRuiz F, Hoffmeyer M, Ianora A, Kang H-K, Laabir M, Lacoste A, Miralto A, Ning X, Poulet S, Rodriguez V, Runge J, Shi J, Starr M, Uye S, Wang Y (1997) The paradox of diatom-copepod interactions. Mar Ecol Prog Ser 157:287-293

Barofsky A, Simonelli P, Vidoudez C, Troedsson C, Nejstgaard J, Jakobsen H, Pohnert G (2010) Growth phase of the diatom Skeletonema marinoi influences the metabolic profile of the cells and the selective feeding of the copepod Calanus spp. J Plankton Res 32:263-272

Besiktepe S, Dam HG (2002) Coupling of ingestion and defecation as a function of diet in the calanoid copepod Acartia tonsa. Mar Ecol Prog Ser 229:151-164.

Brown M, Dunstan G, Norwood S, Miller K (1996) Effects of harvest stage and light on the biochemical composition of the diatom Thalassiosira pseudonana. J Phycol 32:64-73

Caldwell G, Bentley M, Olive P (2004) First evidence of sperm motility inhibition by the diatom aldehyde 2E,4E-decadienal. Mar Ecol Prog Ser 273:97-108.

Carotenuto Y, Wichard T, Pohnert G, Lampert W (2005) Life-history responses of Daphnia pulicaria to diets containing freshwater diatoms: Effects of nutritional quality versus polyunsaturated aldehydes. Limnol Oceanogr 50:449-454.

Castellani C, Irigoien X, Mayor D, Harris R, Wilson D (2008) Feeding of Calanus finmarchicus and Oithona similis on the microplankton assemblage in the Irminger Sea, North Atlantic. J Plankton Res 30:1095-1116.

Claustre H, Marty J-C, Cassiani L (1989) Intraspecific differences in the biochemical composition of a diatom during a spring bloom in Villefranche-sur-Mer Bay, Mediterranean Sea. J Exp Mar Biol Ecol 129:17-32

Debes H, Eliasen K, Gaard E (2008) Seasonal variability in copepod ingestion and egg production on the Faroe shelf. Hydrobiologia 600:247-265

Dutz J, Koski M, Jónasdóttir SH (2008) Copepod reproduction is unaffected by diatom aldehydes or lipid composition. Limnol Oceanogr 53:225-235

Erga SR (1989) Ecological studies on the phytoplankton of Boknafjorden, Western Norway. 1. The effect of water exchange processes and environmental factors on temporal and vertical variability of biomass. Sarsia 74:161-176

Erga SR, Heimdal BR (1984) Ecological studies on the phytoplankton of Korsfjorden, western Norway: the dynamics of a spring bloom seen in relation to hydrographical conditions and light regime. J Plankton Res 6:67-90

Fransz, HG, Colebrook, JM, Gamble, JC and Krause M. (1991) The zooplankton of the North Sea. Neth, J. Sea Res. 28:1-52

Harrison P, Conway H, Holmes R, Davis C (1977) Marine diatoms grown in chemostats under silicate or ammonium limitation. III. Cellular chemical composition and morphology of Chaetoceros debilis, Skeletonema costatum, and Thalassiosira gravida. Mar Biol 43:19-31

Hassett R (2004) Supplementation of a diatom diet with cholesterol can enhance copepod eggproduction rates. Limnol Oceanogr 49:488-494

Heath MR (1999) The ascent migration of Calanus finmarchicus from overwintering depth in the Faroe-Shetland Channel. Fish Oceanogr 8:84-99 
Ianora A, Miralto A, Poulet S, Carotenuto Y, Buttino I, Romano G, Casotti R, Pohnert G, Wichard T, Colucci-D'Amato L, Terrazzano G, Smetacek V (2004) Aldehyde suppression of copepod recruitment in blooms of a ubiquitous planktonic diatom. Nature 429:403-407

Ianora A, Poulet S, Miralto A (1995) A comparative study of the inhibitory effect of diatoms on the reproductive biology of the copepod Temora stylifera. Mar Biol 121:533-539

Ianora A, Poulet S, Miralto A (2003) The effects of diatoms on copepod reproduction: a review. Phycologia 42:351-363

Irigoien X, Head R, Harris R, Cummings D, Harbour D, Meyer-Harms B (2000) Feeding selectivity and egg production of Calanus helgolandicus in the English Channel. Limnol Oceanogr 45:4454

Irigoien X, Titelman J, Harris RP, Harbour D, Castellani C (2003) Feeding of Calanus finmarchicus nauplii in the Irminger Sea. Mar Ecol Prog Ser 262:193-200

Irigoien X, Verheye H, Harris R, Harbour D (2005) Effect of food composition on egg production and hatching success rate of two copepod species (Calanoides carinatus and Rhincalanus nasutus) in the Benguela upwelling system. J Plankton Res 27:735-742.

Jónasdóttir SH (1994) Effects of food quality on the reproductive success of Acartia tonsa and Acartia hudsonica: laboratory observations. Mar Biol 121:67-81

Jónasdóttir SH, Kiørboe T (1996) Copepod recruitment and food composition: do diatoms affect hatching success? Mar Biol 125:743-750

Jónasdóttir SH, Kiørboe T, Tang K, St.John M, Visser A, Saiz E, Dam H (1998) Role of diatoms in copepod production: good, harmless or toxic? Mar Ecol Prog Ser 172:305-308

Jónasdóttir SH, Richardson K, Heath MR, Ingvarsdóttir A, Christoffersen A (2008) Spring production of Calanus finmarchicus at the Iceland-Scotland Ridge. Deep-Sea Res I 55:471-489.

Jónasdóttir SH, Trung N, Hansen F, Gärtner S (2005) Egg production and hatching success in the calanoid copepods Calanus helgolandicus and Calanus finmarchicus in the North Sea from March to September 2001. J Plankton Res 27:1239-1259

Klein Breteler W, Schogt N, Rampen S (2005) Effect of diatom nutrient limitation on copepod development: role of essential lipids. Mar Ecol Prog Ser 291:125-133

Kleppel G, Holliday D, Pieper R (1991) Trophic interactions between copepods and microplankton: A question about the role of diatoms. Limnol Oceanogr 36:172-178

Koski M (2007) High reproduction of Calanus finmarchicus during a diatom-dominated bloom. Mar Biol 151:1785-1798

Koski M, Riser C (2006) Post-bloom feeding of Calanus finmarchicus copepodites: Selection for autotrophic versus heterotrophic prey. Marine Biology Research 2:109-119

Koski M, Wichard T, Jónasdóttir SH (2008) "Good" and "bad" diatoms: development, growth and juvenile mortality of the copepod Temora longicornis on diatom diets. Mar Biol 154:719-734

Lepage G, and Roy Cc (1984) Improved Recovery of Fatty-Acid through Direct TransEsterification without Prior Extraction or Purification. Journal of Lipid Research 25:1391-1396

Mayor D, Anderson T, Irigoien X, Harris R (2006) Feeding and reproduction of Calanus finmarchicus during non-bloom conditions in the Irminger Sea. J Plankton Res 28:1167-1179

Md Amin R, Koski M, Båmstedt U (2011) Strain-related physiological and behavioral effects of Skeletonema marinoi on three common planktonic copepods. Mar Biol ?:??-??

Menden-Deuer S, Lessard E (2000) Carbon to volume relationships for dinoflagellates, diatoms, and other protist plankton. Limnol Oceanogr 45:569-579

Meyer-Harms B, Irigoien X, Head R, Harris R (1999) Selective feeding on natural phytoplankton by Calanus finmarchicus before, during, and after the 1997 spring bloom in the Norwegian Sea. Limnol Oceanogr 44:154-165

Miralto A, Barone G, Romano G, Poulet S, Ianora A, Russo G, Buttino I, Mazzarella G, Laabir M, Cabrini M, Giavobbe M (1999) The insidious effect of diatoms on copepod reproduction. Nature 402:173-176

Nejstgaard J, Frischer M, Verity P, Anderson J, Jacobsen A, Zirbel M, Larsen A, MartínezMartínez J, Sazhin A, Walters T, Bronk D, Whipple S, Borrett S, Patten B, Long J (2006) 
Plankton development and trophic transfer in seawater enclosures with nutrients and Phaeocystis pouchetii added. Mar Ecol Prog Ser 321:99-121

Nejstgaard J, Gismervik I, Solberg P (1997) Feeding and reproduction by Calanus finmarchicus, and microzooplankton grazing during mesocosm blooms of diatoms and the coccolithophore Emiliana huxleyi. Mar Ecol Prog Ser 147:197-217

Nejstgaard J, Hygum B, Naustvoll L-J, Båmstedt U (2001a) Zooplankton growth, diet and reproductive success compared in simultaneous diatom- and flagellate- microzooplanktondominated plankton blooms. Mar Ecol Prog Ser 221:77-91

Nejstgaard JC, Naustvoll L-J, Sazhin A (2001b) Correcting for underestimation of microzooplankton grazing in bottle incubation experiments with mesozooplankton. Mar Ecol Prog Ser 221:59-75

Nichols P, Skerrat J, Davidson A, Burton H, McMeekin T (1991) Lipids of cultured Phaeocystis pouchetii: signatures for food-web, biogeochemical and environmental studies in Antarctica and the Southern Ocean. Phytochemistry 30:3209-3214

Niehoff B, Klenke U, Hirche H-J, Head R, Harris R (1999) A high frequency time series at Weathership M, Norwegian Sea, during the 1997 spring bloom: the reproductive biology of Calanus finmarchicus. Mar Ecol Prog Ser 176:81-92

Pohnert G, Lumineau O, Cueff A, Adolph S, Cordevant C, Lange M, Poulet S (2002) Are volatile unsaturated aldehydes from diatoms the main line of chemical defence against copepods? Mar Ecol Prog Ser 245:33-45

Poulet S, Ianora A, Miralto A, Meijer L (1994) Do diatoms arrest embryonic development in copepods? Mar Ecol Prog Ser 111:79-86

Rey C, Carlotti F, Tande K, Hygum BH (1999) Egg and faecal pellet production of Calanus finmarchicus females from controlled mesocosms and in situ populations: influence of age and feeding history. Mar Ecol Prog Ser 188:133-148

Rey C, Harris R, Irigoien X, Head R, Carlotti F (2001) Influence of algal diet on growth and ingestion of Calanus helgolandicus nauplii. Mar Ecol Prog Ser 216:151-165

Ribalet F, Wichard T, Pohnert G, Ianora A, Miralto A, Casotti R (2007) Age and nutrient limitation enhance polyunsaturated aldehyde production in marine diatoms. Phytochemistry 68:2059-2067

Richardson K, Jónasdóttir SH, Hay SJ, Christoffersen A (1999) Calanus finmarchicus egg production and food availability in the Faroe-Shetland Channel and northern North Sea: October-March. Fish Oceanogr 8 (suppl. 1):153-162

Sarno D, Kooistra W, Medlin L, Percopo I, Zingone A (2005) Diversity in the genus Skeletonema (bacillariophyceae). II. An assessment of the taxonomy of $S$. costatum-like species with the description of four new species. J Phycol 41:151-176

Takabayashi, M., Lew, K., Johnson, A., Marchi, A., Dugdale, R., and Wilkerson, F. P. (2006) The effect of nutrient availability and temperature on chain length of the diatom, Skeletonema costatum. J Plankton Res 28:831-840.

Taylor R, Abrahamsson K, Godhe A, Wängberg S-Å (2009) Seasonal variability in polyunsaturated aldehyde production potential among strains of Skeletonema marinoi (Bacillariophyceae). J Phycol 45:46-53

Taylor R, Caldwell G, Dunstan H, Bentley M (2007) Short-term impacts of polyunsaturated aldehyde-producing diatoms on the harpacticoid copepod, Tisbe holothuriae. J Exp Mar Biol Ecol 341:60-69

Vidoudez C, Casotti R, Bastianini M, Pohnert G (2011a) Quantification of dissolved and particulate polyunsaturated aldehydes in the Adriatic Sea. Mar Drugs 9:500-513; doi:10.3390/md9040500

Vidoudez C, Nejstgaard JC, Jakobsen HH, Pohnert G (2011b) Dynamics of dissolved and particulate polyunsaturated aldehydes in mesocosms inoculated with different densities of the diatom Skeletonema marinoi. Mar Drugs 9:345-358; doi:10.3390/md9030345

Vidoudez C, Pohnert G (2008) Growth phase-specific release of polyunsaturated aldehydes by the diatom Skeletonema marinoi. J Plankton Res 30:1305-1313

Viso A-C, Marty J-C (1993) Fatty acids from 28 marine microalgae. Phytochemistry 34:1521-1533 
Wichard T, Gerecht A, Boersma M, Poulet S, Wiltshire K, Pohnert G (2007) Lipid and fatty acid composition of diatoms revisited: Rapid wound-activated change of food quality parameters influences herbivorous copepod reproductive success. Chem Bio Chem 8:1146-1153

Wichard T, Poulet S, Boulesteix A-L, Ledoux J, Lebreton B, Marchetti J, Pohnert G (2008) Influence of diatoms on copepod reproduction. II. Uncorrelated effects of diatom-derived $\alpha, \beta, \gamma, \delta$-unsaturated aldehydes and polyunsaturated fatty acids on Calanus helgolandicus in the field. Prog Oceanog 77:30-44

Wichard T, Poulet S, Pohnert G (2005) Determination and quantification of $\alpha, \beta, \gamma, \delta$-unsaturated aldehydes as pentafluorobenzyl-oxime derivates in diatom cultures and natural phytoplankton populations: application in marine field studies. Journal of Chromatography B 814:155-161 Williams PJLB, Egge JK (1998) The management and behaviour of the mesocosms. Est Coast Shelf Sci 46:3-14 
Figure Legends:

737 Fig. 1 Daily development of a) total Chl $a$ and b) Chl $a$ in size fraction $>10 \mu m\left(\mu g L^{-1}\right)$ in 738 mesocosms: B (added phosphate and nitrate), C (added phosphate, nitrate and silicate), E (added 739 phosphate, nitrate, silicate and 400 S. marinoi $\mathrm{L}^{-1}$ ) and $\mathrm{F}$ (added phosphate, nitrate, silicate and 400 740 S. marinoi $\mathrm{L}^{-1}$ ) and the untreated water outside the mesocosms (Ambient). For detailed description 741 of the mesocosm treatments see Materials and Methods. Shaded area shows the days not used in the 742 analysis for EPR.

Fig. 2 Daily development of A) protoplankton biomass ( $\mu \mathrm{g} \mathrm{C} \mathrm{L}^{-1}$ ) and B) \% composition from day 4 in the ambient seawater and in mesocosm B, C, E and F. Black fill: the diatom Skeletonema marinoi, hatched fill: ciliates, white fill: total heterotrophic dinoflagellates (sum of Gyrodinium spirale, G. dominans and Protoperidinium bipebs) and stippled fill: the cryptophyte Phaeocystis pouchetii

Fig. 3 Daily development of total fatty acids, monounsaturated fatty acids (MUFA), polyunsaturated fatty acids (PUFA), and total sterols, chole-, brassica-, sitosterols (all $\mu \mathrm{g} \mathrm{L}^{-1}$ ) in the mesocosms B, C, E and F and ambient water. Symbols as in figure 1.

Fig. 4 Daily development of Calanus finmarchicus a) egg production rate (EPR: eggs female ${ }^{-1}$ day $^{-}$ 755 ${ }^{1}$ ), b) fraction of females producing eggs, c) egg hatching success (\%), and d) faecal pellet production (FPR: $\mu \mathrm{m}^{3}$ female ${ }^{-1}$ day $^{-1} \times 10^{6}$ ) from mesocosms B, C, E and F and the ambient water (from day 7). EPR shows additionally EPR from filtered seawater incubation (day 3-6).

Fig. 5 Calanus finmarchicus egg production rate (eggs female ${ }^{-1}$ day $^{-1}$ ) as a function of protoplankton biomass a) P. pouchetii, b)ciliates, c) S. marinoi, and d) G. dominans, e) total carbon concentration of protoplankton (all in $\mu \mathrm{gC} \mathrm{L}^{-1}$ ) and f) concentration of the fatty acid 22:6(n-3) ( $\mu \mathrm{g}$ $\left.\mathrm{L}^{-1}\right)$. Symbols as in Figure 1.

Fig. 6 Relation between the residuals of the regression presented in Figure 5e and the carbon based proportion of a) S. marinoi and b) $P$. pouchetii and the concentrations of c) particulate PUA ( $\mu \mathrm{L} \mathrm{L}^{-1}$ ) and d) dissolved PUA (nM). protoplankton biomass a) P. pouchetii, b)ciliates, c) S. marinoi, and d) G. dominans, e) total carbon 
770 concentration of protoplankton (all in $\left.\mu g \mathrm{C} \mathrm{L}^{-1}\right)$ and f) concentration of the fatty acid 22:6(n-3) ( $\mu \mathrm{g}$ $\left.771 \mathrm{~L}^{-1}\right)$. Symbols as in Figure 1.

772

773 Fig. 8 Correlation between Calanus finmarchicus egg production rate (eggs female ${ }^{-1}$ day $^{-1}$ ) and 774 faecal pellet production $\left(\mu \mathrm{m}^{3}\right.$ female $^{-1}$ day $^{-1}$ x $\left.10^{6}\right)$. Symbols as in Fig 1. 
Table 1. Calanus finmarchicus biological rates in the different experimental treatments. Average egg production rate (EPR: eggs female ${ }^{-1}$ day $^{-1}$ ), cumulative egg production (eggs), non producing females (\% Fem w/o eggs), female mortality (\%), hatching success (H\%), faecal volume production (FPR: $\mu \mathrm{m}^{3}$ female $^{-1}$ day $^{-1} \times 10^{6}$ ) and faecal pellet production (\# pellets: no. pellets female ${ }^{-1}$ day $^{-1}$ ). FSW: 0.2 $\mu \mathrm{m}$ filtered seawater control during days 3-6. Amb: ambient seawater control during days 7-14. All averages list \pm SE.

779

\begin{tabular}{|c|c|c|c|c|c|c|c|c|c|c|c|c|}
\hline $\begin{array}{c}\text { Mesocos } \\
\mathrm{m}\end{array}$ & \multicolumn{4}{|c|}{ Treatment additions } & \multirow[t]{2}{*}{$\begin{array}{c}\mathrm{EPR} \pm \mathrm{SE} \\
\text { Day 5-14 }\end{array}$} & \multirow[t]{2}{*}{$\begin{array}{l}\text { EPR range } \\
\text { Day 5-14 }\end{array}$} & \multirow[t]{2}{*}{$\begin{array}{c}\text { Cum EPR } \\
\text { Day 5-14 }\end{array}$} & \multirow[t]{2}{*}{$\begin{array}{c}\text { \% Fem } \\
\text { w/o eggs }\end{array}$} & \multirow[t]{2}{*}{$\begin{array}{c}\% \\
\text { Mortality }\end{array}$} & \multirow[t]{2}{*}{$\begin{array}{c}\mathrm{H} \% \pm \mathrm{SE} \\
\text { Day 5-14 }\end{array}$} & \multirow[t]{2}{*}{$\begin{array}{c}\text { FPR x } 10^{6} \\
\text { Day 3-14 }\end{array}$} & \multirow[t]{2}{*}{$\begin{array}{l}\text { \# Pellets } \\
\text { Day 3-14 }\end{array}$} \\
\hline & $\mathrm{N}$ & $\mathrm{P}$ & $\mathrm{Si}$ & S. marinoi & & & & & & & & \\
\hline $\mathrm{B}$ & 4.24 & 0.4 & - & - & $32 \pm 6$ & $0-173$ & 4497 & 23 & 35 & $83 \pm 2$ & $25 \pm 2$ & $27 \pm 2$ \\
\hline $\mathrm{C}$ & 4.24 & 0.4 & 3.61 & - & $46 \pm 8$ & $0-202$ & 7959 & 15 & 20 & $88 \pm 2$ & $54 \pm 4$ & $43 \pm 2$ \\
\hline $\mathrm{E}$ & 4.24 & 0.4 & 3.61 & 400 & $45 \pm 7$ & $0-232$ & 5863 & 23 & 40 & $86 \pm 3$ & $45 \pm 4$ & $40 \pm 3$ \\
\hline $\mathrm{F}$ & 4.24 & 0.4 & 3.61 & 1000 & $42 \pm 8$ & $0-167$ & 8039 & 12 & 0 & $89 \pm 3$ & $43 \pm 2$ & $42 \pm 2$ \\
\hline $\mathrm{FSW}_{\mathrm{d} 3-6}$ & - & - & - & - & $6 \pm 3$ & $0-38$ & - & 47 & - & - & - & $9 \pm 3$ \\
\hline $\mathrm{Amb}_{\mathrm{d}} 7-14$ & - & - & - & - & $9 \pm 5$ & $0-90$ & - & 50 & 20 & $89 \pm 2$ & $4 \pm 0.5$ & $11 \pm 2$ \\
\hline
\end{tabular}


Table 2. Development of the major fatty acids in mesocosms B, C, E and F. The fatty acids 20:3(n-

785

\begin{tabular}{|c|c|c|c|c|c|c|c|c|c|c|c|c|}
\hline Day & $\begin{array}{l}16: 1 \\
(n-7)\end{array}$ & $\begin{array}{l}18: 1 \\
(n-9)\end{array}$ & $\begin{array}{l}18: 2 \\
(n-6)\end{array}$ & $\begin{array}{l}18: 3 \\
(n-3)\end{array}$ & $\begin{array}{l}18: 3 \\
(n-6)\end{array}$ & $\begin{array}{r}\mathbf{2 0 : 1} \\
\mathbf{( n - 9 )} \\
\mu g(\mathrm{c})\end{array}$ & $\begin{array}{c}20: 2 \\
(\mathbf{n}-6) \\
n 1 L)^{-}\end{array}$ & $\begin{array}{l}20: 4 \\
(n-6)\end{array}$ & $\begin{array}{l}20: 5 \\
(n-3)\end{array}$ & $\begin{array}{l}22: 1 \\
(n-9)\end{array}$ & $\begin{array}{l}22: 2 \\
(n-6)\end{array}$ & $\begin{array}{l}22: 6 \\
(n-3)\end{array}$ \\
\hline \multicolumn{13}{|c|}{ Mesocosm B } \\
\hline 0 & $\mathrm{~T}$ & 2.6 & 1.2 & 1.5 & 7.0 & 0.3 & $\mathrm{~T}$ & $\mathrm{~T}$ & 3.2 & 0.6 & 0.7 & 4.7 \\
\hline 1 & $\mathrm{~T}$ & 1.9 & 0.8 & 1.1 & 9.6 & 0.2 & $\mathrm{~T}$ & $\mathrm{~T}$ & 3.0 & 0.5 & 0.5 & 4.6 \\
\hline 2 & $\mathrm{~T}$ & $\mathrm{~T}$ & 0.5 & 0.6 & 6.2 & $\mathrm{~T}$ & $\mathrm{~T}$ & $\mathrm{~T}$ & 1.9 & 0.3 & 0.3 & 3.2 \\
\hline 3 & $\mathrm{~T}$ & 1.9 & 1.3 & 1.4 & 14.9 & n.d. & n.d. & n.d. & 2.3 & 0.3 & $\mathrm{~T}$ & 4.4 \\
\hline 4 & 9.8 & 4.0 & 2.9 & 4.9 & 51.3 & 0.3 & n.d. & 0.7 & 7.3 & 0.3 & 0.4 & 20.3 \\
\hline 5 & 10.5 & 3.5 & 2.8 & 4.4 & 59.8 & 0.3 & n.d. & 1.3 & 12.4 & 0.3 & 0.4 & 32.4 \\
\hline 6 & 9.0 & 5.2 & 3.1 & 4.2 & 59.6 & 0.3 & n.d. & 1.1 & 10.7 & 0.4 & n.d. & 56.3 \\
\hline 7 & 8.4 & 6.0 & 3.3 & 3.6 & 44.9 & 0.4 & n.d. & $\mathrm{T}$ & 6.3 & $\mathrm{~T}$ & 0.4 & 34.4 \\
\hline 8 & 15.8 & 9.8 & 5.7 & 7.1 & 91.6 & 0.9 & n.d. & 2.5 & 15.5 & $\mathrm{~T}$ & 0.9 & 81.1 \\
\hline 9 & n.d. & 15.1 & 6.9 & 6.5 & 60.1 & 1.1 & n.d. & 3.0 & 11.2 & $\mathrm{~T}$ & 1.0 & 55.6 \\
\hline 10 & $\mathrm{~T}$ & 23.4 & 15.3 & 11.8 & 132.8 & 1.9 & n.d. & $\mathrm{T}$ & 12.7 & $\mathrm{~T}$ & 2.4 & 72.7 \\
\hline 11 & n.d. & 19.7 & 13.0 & 9.4 & 83.4 & 1.8 & n.d. & $\mathrm{T}$ & 13.1 & $\mathrm{~T}$ & 1.6 & 84.9 \\
\hline 12 & 17.6 & 26.6 & 22.7 & 22.2 & 164.9 & 2.0 & 4.6 & $\mathrm{~T}$ & 25.0 & n.d. & 1.7 & 196.4 \\
\hline 13 & 17.3 & 25.7 & 21.2 & 14.7 & 124.3 & 1.9 & 4.4 & $\mathrm{~T}$ & 14.1 & 2.2 & 2.1 & 129.4 \\
\hline \multicolumn{13}{|c|}{ Mesocosm C } \\
\hline 0 & $\mathrm{~T}$ & 1.7 & 1.0 & 1.0 & 5.9 & 0.3 & n.d. & n.d. & n.d. & 0.7 & 0.7 & 3.6 \\
\hline 1 & $\mathrm{~T}$ & 1.7 & 0.8 & 1.3 & 14.3 & 0.3 & n.d. & $\mathrm{T}$ & n.d. & 0.8 & 0.7 & 6.5 \\
\hline 2 & $\mathrm{~T}$ & 1.3 & 0.5 & 0.7 & 8.5 & 0.3 & n.d. & $\mathrm{T}$ & $\mathrm{T}$ & 0.4 & 0.3 & 4.1 \\
\hline 3 & $\mathrm{~T}$ & 1.7 & 0.8 & 1.3 & 9.8 & 0.2 & n.d. & $\mathrm{T}$ & 1.8 & 0.3 & 0.2 & 5.6 \\
\hline 4 & 11.3 & 3.5 & 1.8 & 3.6 & 40.9 & 0.2 & $\mathrm{~T}$ & 0.8 & 7.7 & 0.3 & 0.6 & 27.6 \\
\hline 5 & 15.9 & 4.3 & 2.8 & 5.4 & 57.5 & 0.2 & $\mathrm{~T}$ & 1.2 & 8.7 & 0.3 & 0.6 & 44.2 \\
\hline 6 & 21.6 & 5.4 & 3.5 & 7.4 & 77.2 & 0.3 & $\mathrm{~T}$ & 1.1 & 14.8 & 0.5 & 1.1 & 59.5 \\
\hline 7 & 21.6 & 5.7 & 2.6 & 5.2 & 68.6 & 0.5 & $\mathrm{~T}$ & 1.6 & 13.3 & 0.6 & 1.0 & 50.2 \\
\hline 8 & 16.5 & 7.4 & 3.9 & 5.2 & 51.0 & 0.9 & $\mathrm{~T}$ & 2.6 & 13.7 & 1.2 & 1.1 & 47.5 \\
\hline 9 & 15.6 & 8.0 & 3.7 & 4.1 & 50.1 & 0.8 & $\mathrm{~T}$ & $\mathrm{~T}$ & 14.0 & 1.2 & 1.0 & 37.6 \\
\hline 10 & 9.1 & 9.8 & n.d. & 5.5 & 57.4 & 1.1 & $\mathrm{~T}$ & $\mathrm{~T}$ & 11.1 & 1.5 & 1.3 & 42.7 \\
\hline 11 & 31.8 & 11.2 & 8.2 & 7.1 & n.d. & 1.2 & n.d. & $\mathrm{T}$ & 16.2 & 1.5 & 1.4 & 63.9 \\
\hline 12 & 26.9 & 10.9 & 7.2 & 5.3 & 50.3 & 1.2 & n.d. & $\mathrm{T}$ & 9.1 & 1.5 & 1.3 & 43.9 \\
\hline 13 & 92.4 & 22.5 & 23.2 & 15.6 & 165.4 & 2.1 & 4.6 & 5.5 & 27.5 & 2.3 & 2.6 & 226.2 \\
\hline \multicolumn{13}{|c|}{ Mesocosm E } \\
\hline 0 & n.d. & $\mathrm{T}$ & 0.6 & 0.9 & 4.9 & n.d. & n.d. & n.d. & n.d. & n.d. & 0.4 & 2.4 \\
\hline 1 & n.d. & $\mathrm{T}$ & n.d. & 0.6 & 4.8 & n.d. & n.d. & n.d. & $\mathrm{T}$ & n.d. & 0.2 & 1.4 \\
\hline 2 & n.d. & n.d. & 0.5 & 0.5 & 3.8 & $\mathrm{~T}$ & n.d. & n.d. & $\mathrm{T}$ & $\mathrm{T}$ & $\mathrm{T}$ & 0.9 \\
\hline 3 & 10.7 & 1.8 & 1.3 & 3.1 & 22.0 & 0.2 & n.d. & 0.6 & 6.3 & 0.3 & 0.3 & 16.8 \\
\hline 4 & n.m. & n.m. & n.m. & n.m. & n.m. & n.m. & n.m. & n.m. & n.m. & n.m. & n.m. & n.m. \\
\hline 5 & 76.0 & n.d. & 1.8 & n.d. & 95.7 & n.d. & n.d. & n.d. & $\mathrm{T}$ & n.d. & n.d. & 93.0 \\
\hline 6 & n.d. & n.d. & 2.2 & n.d. & 134.8 & n.d. & n.d. & n.d. & $\mathrm{T}$ & n.d. & n.d. & 79.5 \\
\hline 7 & 108.4 & n.d. & 2.4 & n.d. & 74.9 & n.d. & n.d. & n.d. & $\mathrm{T}$ & n.d. & n.d. & 57.1 \\
\hline 8 & 159.5 & $\mathrm{~T}$ & 2.9 & 7.6 & 64.2 & n.d. & n.d. & n.d. & 21.6 & n.d. & n.d. & 67.7 \\
\hline 9 & 191.9 & 7.2 & 4.6 & 9.2 & 96.5 & n.d. & n.d. & n.d. & 22.2 & n.d. & $\mathrm{T}$ & 86.8 \\
\hline 10 & 145.4 & 13.1 & 8.1 & 9.0 & 87.0 & 1.0 & n.d. & 3.4 & 36.1 & 1.1 & 1.1 & 80.4 \\
\hline 11 & 67.9 & 12.5 & 7.1 & 8.5 & 53.5 & 1.0 & n.d. & $\mathrm{T}$ & 23.9 & 1.1 & 0.9 & 75.1 \\
\hline 12 & 147.0 & 18.1 & 12.7 & 13.0 & 96.1 & $\mathrm{~T}$ & 2.3 & $\mathrm{~T}$ & 49.7 & 1.2 & 1.1 & 142.4 \\
\hline 13 & 81.0 & 12.5 & 7.7 & 8.3 & 56.1 & 0.8 & 1.4 & $\mathrm{~T}$ & 24.4 & 0.8 & 0.9 & 87.1 \\
\hline \multicolumn{13}{|c|}{ Mesocosm F } \\
\hline 0 & $\bar{T}$ & 1.8 & 0.6 & 0.9 & 5.4 & $\bar{T}$ & n.d. & n.d. & n.d. & 0.5 & 0.6 & 1.9 \\
\hline 1 & 2.9 & n.d. & 0.5 & 0.5 & 4.5 & 0.2 & n.d. & n.d. & $\mathrm{T}$ & 0.3 & 0.4 & 2.5 \\
\hline 2 & 3.4 & 1.2 & n.d. & 0.5 & 4.7 & 0.2 & n.d. & $\mathrm{T}$ & $\mathrm{T}$ & 0.3 & 0.3 & 2.3 \\
\hline 3 & 9.9 & 1.4 & 0.7 & 1.3 & 10.0 & 0.2 & n.d. & $\mathrm{T}$ & 3.6 & 0.3 & 0.2 & 4.7 \\
\hline 4 & 22.9 & n.d. & 0.6 & 0.8 & 16.3 & n.d. & n.d. & n.d. & $\mathrm{T}$ & n.d. & $\mathrm{T}$ & 10.8 \\
\hline 5 & 108.3 & 2.9 & 1.8 & 5.8 & 82.8 & n.d. & n.d. & 1.3 & 28.7 & n.d. & n.d. & 80.2 \\
\hline 6 & 171.2 & 3.7 & 2.4 & 7.8 & 92.9 & n.d. & n.d. & $\mathrm{T}$ & 52.6 & n.d. & 0.4 & 98.9 \\
\hline 7 & 253.9 & 7.9 & 7.3 & 16.4 & 188.9 & n.d. & n.d. & 2.4 & 71.6 & n.d. & $\mathrm{T}$ & 140.6 \\
\hline 8 & 223.2 & 9.0 & 7.0 & 15.7 & 110.2 & $\mathrm{~T}$ & $\mathrm{~T}$ & 3.8 & 57.1 & n.d. & n.d. & 135.2 \\
\hline 9 & 284.1 & 5.5 & n.d. & 8.7 & 95.6 & n.d. & n.d. & n.d. & 41.0 & n.d. & n.d. & 106.8 \\
\hline 10 & 105.6 & 7.3 & 3.6 & 8.1 & 74.5 & $\mathrm{~T}$ & n.d. & $\mathrm{T}$ & 38.1 & n.d. & n.d. & 111.4 \\
\hline 11 & 123.2 & 8.8 & 4.5 & 8.3 & 59.6 & $\mathrm{~T}$ & n.d. & $\mathrm{T}$ & 42.4 & 0.6 & 0.9 & 104.4 \\
\hline 12 & 183.2 & 14.0 & 4.1 & 11.8 & 79.6 & n.d. & n.d. & n.d. & 49.7 & n.d. & n.d. & 356.3 \\
\hline 13 & 120.3 & 8.8 & 3.6 & 7.4 & 39.6 & 0.4 & n.d. & n.d. & 39.0 & n.d. & $\mathrm{T}$ & 136.4 \\
\hline
\end{tabular}


Table: 3

788 Results from the data reduction by the Principal Component Analysis. The principal components 789 and their \% contribution to explaining the variance in the whole dataset (combined $=87 \%$ ). The 790 scores show the rotated components acquired by using the Equamax method with Kaiser 791 Normalization in 10 iterations. Bold letters show highly correlated variables on each component, 792 bold italic variables that are moderately correlated on that variable. MUFA: mono unsaturated fatty 793 acids.

Octadienal

Heptadienal

Skeletonema marinoi

Decadienal

Chlorophyll $a>10 \mu \mathrm{m}$

MUFA

Cholesterol

Phaeocystis pouchetii

Brassicasterol

Campesterol

Sitosterol

Cilates

Gyrodinium spirale

Protoperidinium bipes

Gyrodinium dominans

Docosahexaenoic acid; 22:6(n-3)

Linoleic acid; 18:3(n-3)

Gamma Linolenic acid 18:3(n-6)

Eicosapentaenoic acid; 20:5(n-3)

\begin{tabular}{cccc}
\multicolumn{4}{c}{ Principal Component } \\
1 & 2 & 3 & 4 \\
$54 \%$ & $17 \%$ & $10 \%$ & $6 \%$ \\
\hline $\mathbf{0 . 9 2}$ & & 0.17 & 0.14 \\
$\mathbf{0 . 9 2}$ & & 0.17 & 0.17 \\
$\mathbf{0 . 8 5}$ & & & 0.39 \\
$\mathbf{0 . 8 1}$ & 0.30 & 0.31 & 0.13 \\
$\mathbf{0 . 7 1}$ & 0.54 & & 0.26 \\
$\mathbf{0 . 6 2}$ & & 0.57 & 0.48 \\
$\mathbf{0 . 6 4}$ & 0.36 & 0.20 & 0.57 \\
0.17 & $\mathbf{0 . 9 1}$ & 0.17 & \\
& $\mathbf{0 . 8 7}$ & & 0.38 \\
& $\mathbf{0 . 8 0}$ & 0.35 & \\
& $\mathbf{0 . 8 0}$ & 0.23 & 0.40 \\
0.31 & 0.17 & $\mathbf{0 . 8 6}$ & \\
& 0.24 & $\mathbf{0 . 8 4}$ & 0.37 \\
& 0.28 & $\mathbf{0 . 8 1}$ & 0.33 \\
0.47 & 0.23 & $\mathbf{0 . 6 1}$ & 0.34 \\
& 0.14 & 0.49 & $\mathbf{0 . 7 9}$ \\
0.20 & 0.41 & 0.33 & $\mathbf{0 . 7 7}$ \\
0.42 & 0.42 & 0.17 & $\mathbf{0 . 7 3}$ \\
& & 0.51 & $\mathbf{0 . 6 6}$
\end{tabular}


799 Results from multiple stepwise regression on Calanus finmarchicus egg production rates (EPR:

800 eggs female $\mathrm{e}^{-1} \mathrm{~d}^{-1}$ ) and faecal pellet production (FPR: $\mu \mathrm{m}^{3}$ female $^{-1} \mathrm{~d}^{-1}$ ) and the food environment, $S$. 801 marinoi, G. dominans, P. pouchetii, ciliates, the fatty acids 22:6(n-3), 20:5(n-3) and cholesterol (or 802 Chl $a$ in the size fraction 5-10 $\mu \mathrm{m}$ ). The stepwise process selects only those variables (labelled 803 “in”) that contribute to the best regression. Variables not in the regression are labelled "out”. Model 804 statistics show $\mathrm{R}^{2}$ : coefficient of determination of the multiple regression, $F_{d f}$ : the $\mathrm{F}$ ratio with $d f$ : 805 degrees of freedom, significance value $p$ of the multiple regression and number of observations $\mathrm{N}$ in 806 the regression. For each variable in the model, "F-to-remove" is the F statistic for its coefficient 807 within the regression; for each variable not in the model, "F-to-enter" is the F statistic that its 808 coefficient would have if it were the next variable added in the regression. $p_{\text {var }}$ : significance of the 809 variable within the regression where $*: p<0.05$, $* * p<0.01, * * * p<0.001$.

810

Variable

Skeletonema marinoi

ciliates

$\mathrm{R}^{2}=0.81$

$\mathrm{F}_{4}=41.7$

$\mathrm{p}<0.001$

$\mathrm{N}=45$

FPR

$\mathrm{R}^{2}=0.78$

$\mathrm{F}_{3}=43.3$

$\mathrm{p}<0.001$

$\mathrm{N}=54$
Gyrodinium dominans

Phaeocystis pouchetii

22:6(n-3)

Cholesterol

20:5(n-3)

Skeletonema marinoi

ciliates

Gyrodinium dominans

Phaeocystis pouchetii

22:6(n-3)

Chlorophyll a 5-10 $\mathrm{mm}$

20:5(n-3)
F-to-remove

6.3

15.0

20.6

27.4

in 27.4

out

out

out

in

8.4

4.5

43.6

10.9

out

out
F-to-enter

p var

\section{$0.016 *$}

$<0.001^{* * *}$

1.1

0.292

$<0.001 * * *$

$0.001 * * *$

$\begin{array}{ll}0.04 & 0.814 \\ 0.04 & 0.961\end{array}$

$1.1 \quad 0.610$

$<0.006^{* *}$

$0.038 *$

$<0.001 * * *$

$0.002 * *$

2.7

0.107

0.339 
Table 5.

Review of concentrations used for studies testing polyunsaturated aldehydes on various biological activities of copepods, cladoceran and echinoderms. All units transferred to nmol L ${ }^{-1}$ (shaded column). Units reported in the respective publications are shown in bold; otherwise calculated from cell numbers and PUA content given in the respective publications. The average molecular weight of $150 \mathrm{~g} \mathrm{~mol}{ }^{-1}$ was used as representative for the most commonly tested decadi- and decatrienal aldehydes. Other aldehyde types have lower molecular weight and therefore transfer to nmol is conservative. Aldehyde types are: HD: Heptadienal, OD: Octadienal, OT: Octatrienal, DE: Decenal, DD: Decadienal, DT: Decatrienal, PUA: Polyunsaturated aldehydes

\begin{tabular}{|c|c|c|c|c|}
\hline \multicolumn{2}{|c|}{ Testing concentrations } & \multirow[t]{2}{*}{ Aldehyde types } & \multirow[t]{2}{*}{ Main effects } & \multirow[t]{2}{*}{ Source } \\
\hline$\mu \mathrm{g} \mathrm{mL}^{-1}$ & $\mathrm{nmol} \mathrm{L}^{-1}$ & & & \\
\hline $0.5-2.0$ & $3,300-13,300$ & $\begin{array}{c}\text { DD } \\
\text { DT-cis } \\
\text { DT-trans }\end{array}$ & $\begin{array}{l}\text { Hatching of Temora longicornis eggs reduced } 10-15 \% \text { at direct exposure of } 3,300 \mathrm{nmol} \mathrm{L}^{-1} \\
\text { DD, } 40-60 \% \text { at } 6,700 \mathrm{nmol} \mathrm{L} \mathrm{L}^{-1} \text { and failed totally at } 10,000-13,000 \mathrm{nmol} \mathrm{L^{-1 }} \text {. } \\
\text { Sea urchin egg division failure at }>3,300 \mathrm{nmol} \mathrm{L^{-1 } D D} \text {. }\end{array}$ & Miralto et al. 1999 \\
\hline $0.6-600$ & $4,000-4,000,000$ & $\begin{array}{l}\text { DD } \\
\text { OD } \\
\text { DD }\end{array}$ & 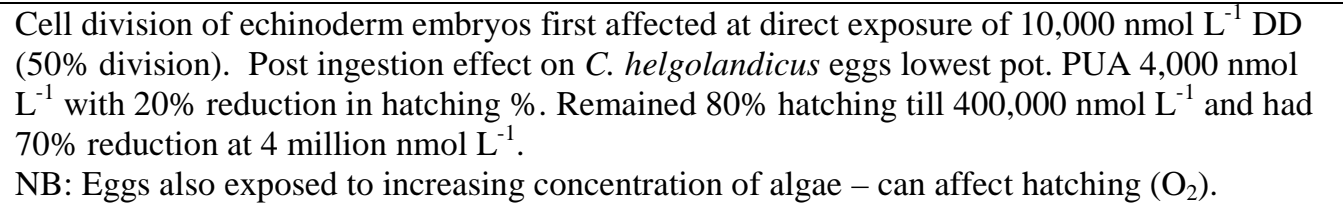 & Adolph et al. 2004 \\
\hline $0.05-50$ & $333-333,000$ & $\overline{\mathrm{DD}}$ & $\begin{array}{l}\text { Motility of starfish sperm decreased with increased direct exposure to DD. } \\
50 \% \text { decrease in motility at } 10,000 \mathrm{nmol} \mathrm{L}^{-1} \text {. }\end{array}$ & Caldwell et al. 2004 \\
\hline $0.5-1.5$ & $3,300-10,000$ & $\mathrm{DD}$ & $\begin{array}{l}\text { Post ingestion effect of the diatom Skeletonema. C. helgolandicus nauplii survive to CII after } \\
3 \& 5 \text { days and to NII after } 7 \text { days of maternal and neonatal feeding. Ingestion ca } 100 \mathrm{pg} \text { DD } \\
\text { female }^{-1} \mathrm{~d}^{-1}=0.0007 \text { [sic. } 0.005 \text { ] nmol female }{ }^{-1} \mathrm{~d}^{-1} \text {. Addition of dissolved DD (direct } \\
\text { exposure) } 10,000 \mathrm{nmol} \mathrm{L}^{-1} \text { to diets resulted in arrested development at CII while } 3,300 \text { and } \\
6,700 \text { nmol DD L }{ }^{-1} \text { addition did not affect development. }\end{array}$ & Ianora et al. 2004 \\
\hline $0.5-4.0$ & $3,300-27,000$ & $\mathrm{DD}$ & $\begin{array}{l}\text { Post ingestion effects of pure diatom diets on Daphnia embryos. First effect of } 50 \% \text { hatching } \\
\text { after } 5 \text { clutches. Direct exposure of developing embryos to DD first affected at }>10,000 \mathrm{nmol} \\
\mathrm{L}^{-1} \text {. }\end{array}$ & $\begin{array}{l}\text { Carotenuto et al. } \\
2005\end{array}$ \\
\hline $1.4-15.0$ & $9,300-100,000$ & $\begin{array}{l}\text { DD } \\
\text { OD } \\
\text { HD }\end{array}$ & $\begin{array}{l}\text { No effect on egg production of Tisbe or hatching after } 3 \text { day feeding on pure diatom diets with } \\
\text { PUA potential. Direct exposure of nauplii to DD showed leathal dose ( } \mathrm{LD}_{50}=50 \% \text { death) } \\
9,300 \mathrm{nmol}^{-1} \text {. Other PUA types less active. Nauplii most sensitive to direct exposure of DD, } \\
\text { females } \mathrm{LD}_{50}>40,000 \mathrm{nmol} \mathrm{L}\end{array}$ & Taylor et al. 2007 \\
\hline $0.1-0.6$ & $53-638$ & $\begin{array}{l}\text { OD } \\
\text { OT } \\
\text { DT }\end{array}$ & $\begin{array}{l}\text { Post ingestion effect of PUA from var. diatom diets tested on copepod T. longicornis. } \\
\text { Ingestion of } 0.1 \mathrm{nmol} \text { PUA female } \mathrm{e}^{-1} \mathrm{~d}^{-1} \text { (should be } 100 \mathrm{pnmol} \mathrm{d}^{-1} \text { not } 100 \mathrm{nmol} \mathrm{d}^{-1} \text { ) did not } \\
\text { negatively affect egg production or hatching success (10 days). PUA sum of OD, OT and DT. }\end{array}$ & Dutz et al. 2008 \\
\hline 0.002 & 11.2 & $\mathrm{HD}$ & Competition of fatty acids in the copepod gut (T. longicornis) when enzymes transform PUFA & Wichard et al. 2007 \\
\hline
\end{tabular}




\begin{tabular}{|c|c|c|c|c|}
\hline & & $\begin{array}{l}\text { OD } \\
\text { OT } \\
\text { DD } \\
\text { DT }\end{array}$ & $\begin{array}{l}\text { to PUA. Supplements of fatty acids improve hatching which is actually not very impaired by } \\
\text { presence of high concentration of PUA. }\end{array}$ & \\
\hline \multicolumn{5}{|c|}{ Measurements in situ } \\
\hline $1 \times 10^{-4}$ & 0.7 & $\begin{array}{l}\text { HD } \\
\text { OD } \\
\text { OT } \\
\text { DD } \\
\text { DT }\end{array}$ & $\begin{array}{l}\text { English Channel natural diatom population during spring. Very high PUA per cell ( } 47 \mathrm{fm}^{\mathrm{f}} \text { cell } \\
{ }^{-} \text {) mainly DT and OD. Values are potential PUA. }\end{array}$ & Wichard et al. 2005 \\
\hline $2 \times 10^{-6}-1 \times 10^{-4}$ & $0.01-1.3$ & $\begin{array}{l}\text { HD } \\
\text { OD } \\
\text { OT }\end{array}$ & $\begin{array}{l}\text { Seasonal PUA concentrations from Gullmarsfjorden, Sweden. Diatoms isolated and tested in } \\
\text { the laboratory. Values are potential PUA. Higher PUA in senescing algae. Highest in } \\
\text { senescing spring population. }\end{array}$ & Taylor et al. 2009 \\
\hline $4 \times 10^{-4}$ & 2.7 & $\begin{array}{l}\text { HD } \\
\text { OD } \\
\text { OT }\end{array}$ & $\begin{array}{l}\text { Natural concentration (sum potential PUA) during spring bloom offshore Dichanto, Chile. } \\
\text { Variation in egg production, low hatching and high abnormal nauplii could not be explained } \\
\text { with natural PUA or doubling of natural PUA concentrations. }\end{array}$ & Poulet et al. 2007 \\
\hline $\begin{array}{l}1 \times 10^{-5}-3 \times 10^{-5} \\
0.002-0.2\end{array}$ & $\begin{array}{l}0.1-0.3 \text { (in situ) } \\
12-143 \text { (exp) }\end{array}$ & $\begin{array}{l}\text { OT } \\
\text { OD } \\
\text { DT } \\
\text { HT }\end{array}$ & $\begin{array}{l}\text { Natural concentration during natural diatom assembly in the English Channel and in feeding } \\
\text { experiments using uni-algal isolates. Sum of potential PUA. Hatching and egg production of } \\
\text { C. helgolandicus positively correlated with diatoms \& PUA. Experiments with high PUA } \\
\text { producers resulted in no effect of PUA on hatching or larval abnormality. }\end{array}$ & Wichard et al. 2008 \\
\hline $2 \times 10^{-5}-0.004$ & $\begin{array}{l}0.1-28 \text { (part) } \\
\mathbf{0}-\mathbf{0 . 1} \text { (dissolved) }\end{array}$ & $\begin{array}{l}\text { HD } \\
\text { OD }\end{array}$ & $\begin{array}{l}\text { Natural concentrations in the Adriatic. Suggests that lysis of Skeletonema marinoi can } \\
\text { contribute significantly to dissolved PUA. One station with the high concentration of both } \\
\text { potential and dissolved PUA. }\end{array}$ & $\begin{array}{l}\text { Vidoudez et al } \\
\text { 2011a }\end{array}$ \\
\hline $\begin{array}{l}0-0.003 \\
0-7 \times 10^{-4}\end{array}$ & $\begin{array}{c}0 \text { - } 17 \text { (part) } \\
0 \text { - } 4.9 \text { (dissolved) }\end{array}$ & $\begin{array}{l}\text { HD } \\
\text { OT } \\
\text { OD } \\
\text { DD } \\
\text { DT }\end{array}$ & $\begin{array}{l}\text { Range of the maximum values measured in mesocosms B, C, E and F. Sum of all measured } \\
\text { dienal and trienal PUAs. Dominant PUA (peak concentration measured), HD }\left(7 \mathrm{nmol} \mathrm{L}^{-1}\right) \text { and } \\
\text { DD }\left(9 \mathrm{nmol} \mathrm{L}{ }^{-1}\right) \text { in mesocosms E\& F. }\end{array}$ & $\begin{array}{l}\text { This study } \\
\text { Vidoudez et al. } \\
\text { 2011b }\end{array}$ \\
\hline
\end{tabular}


a)

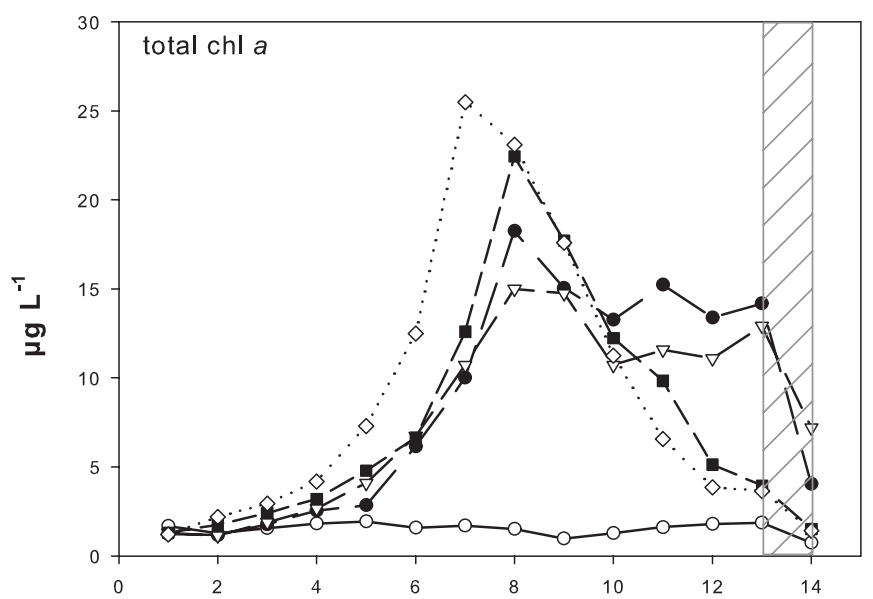

b)

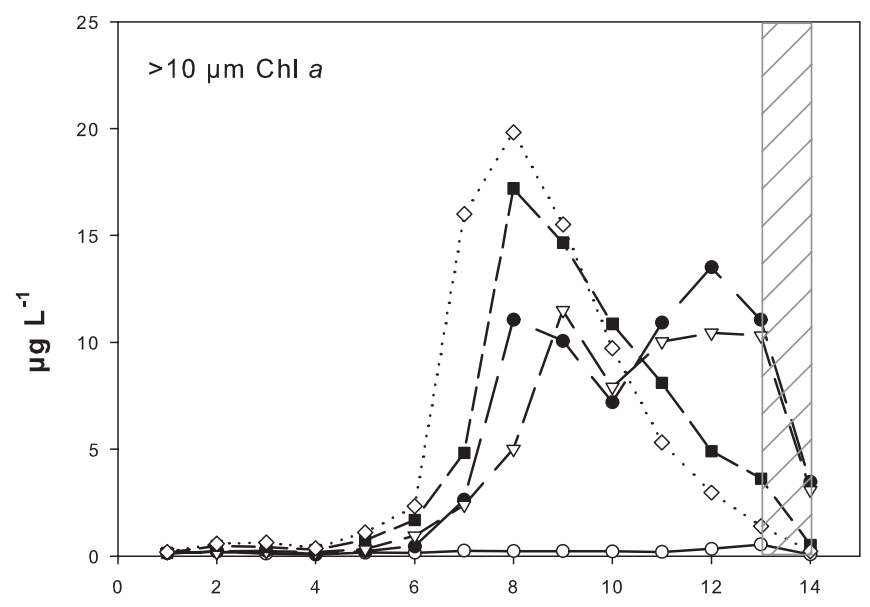

- Ambient

- B

$\nabla \quad C$

- $\mathrm{E}$

$\diamond \quad F$ 
A) Biomass $\mu g \mathrm{C} \mathrm{L}^{-1}$

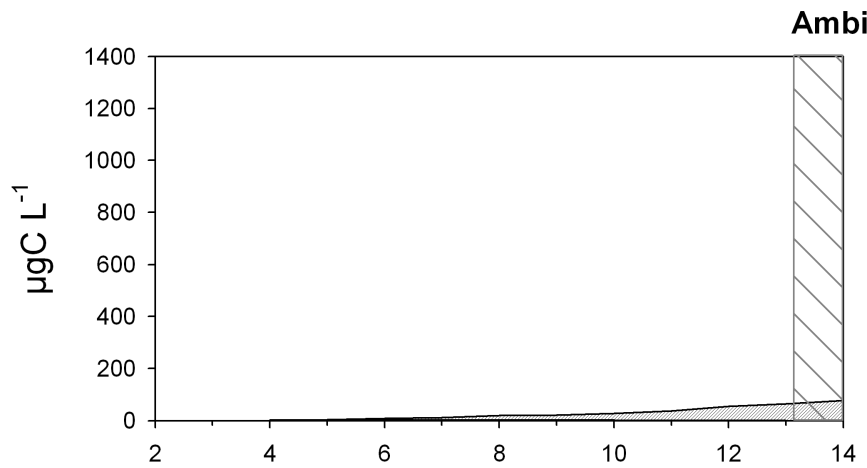

B) $\%$ composition

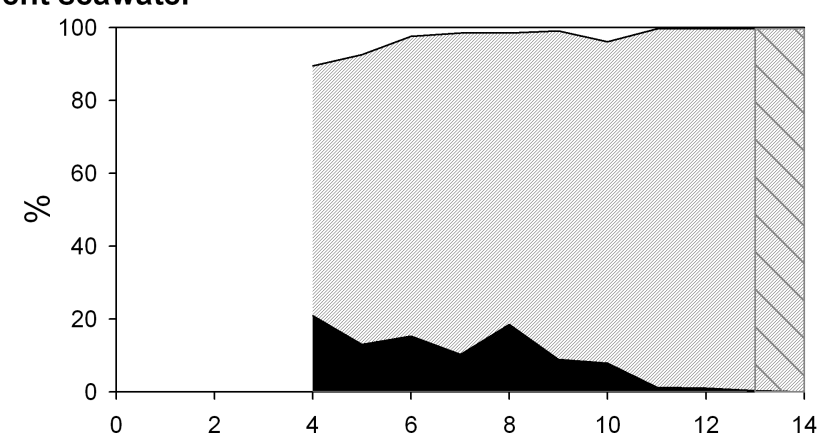

Mesocosm B
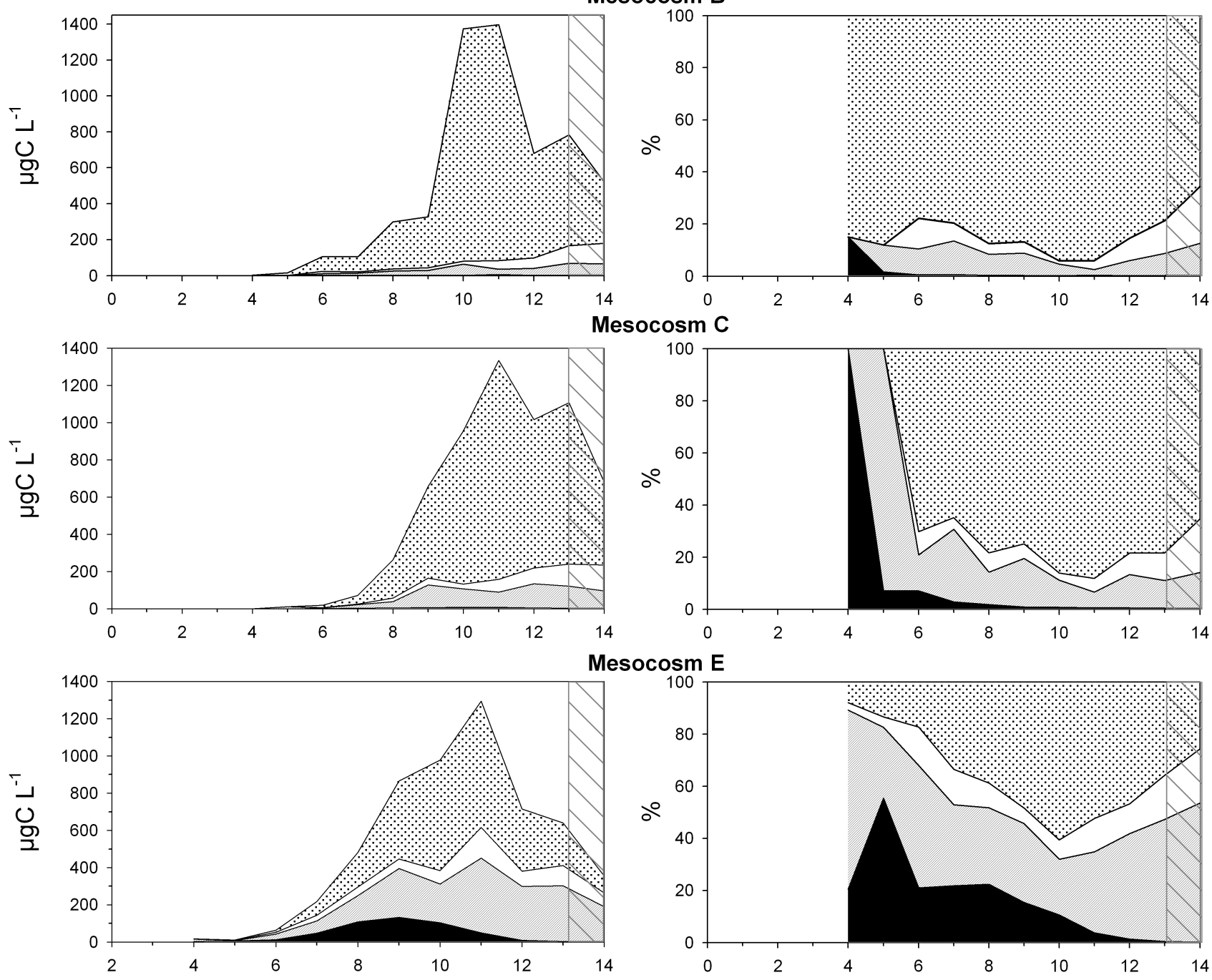

Mesocosm F
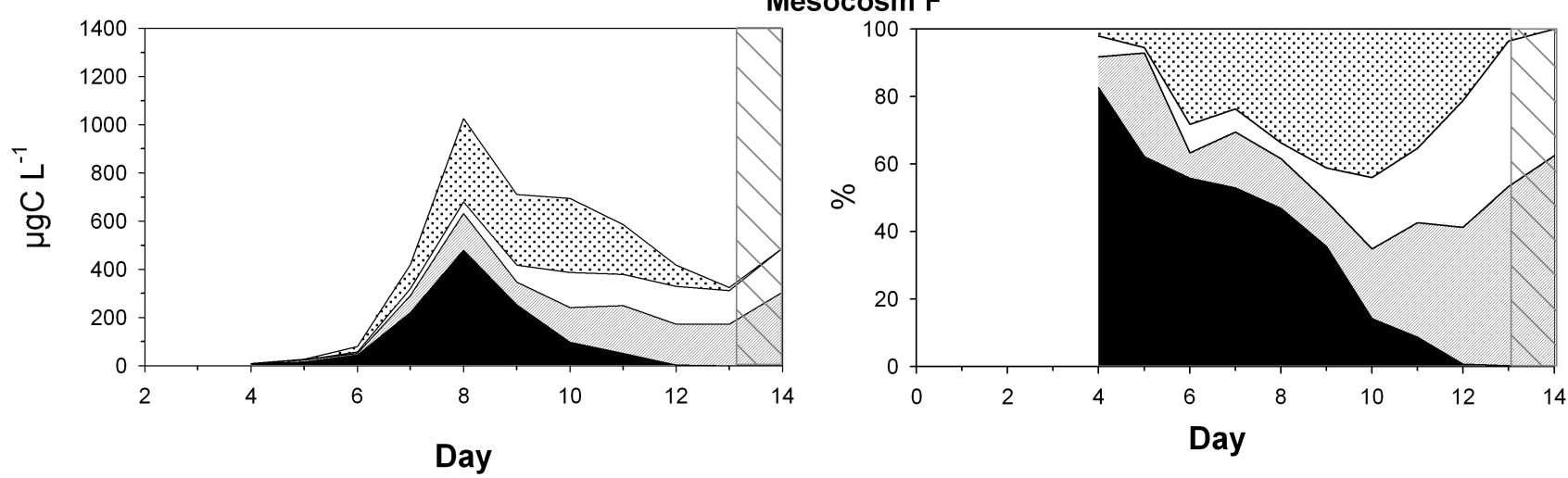

$\because$ Phaeocystis

$\square$ Dinoflagellates

Ciliates

Skeletonema 

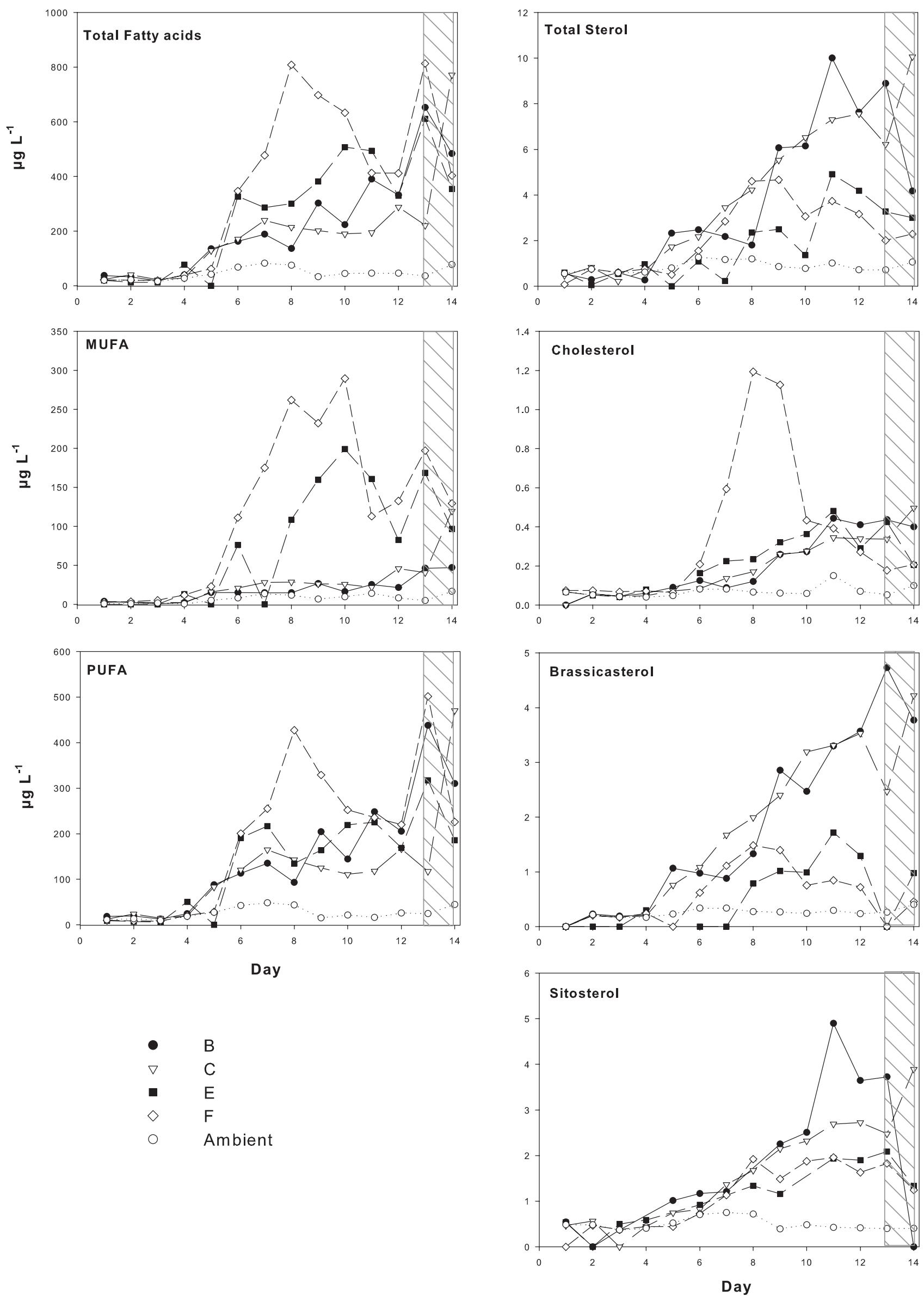
a)

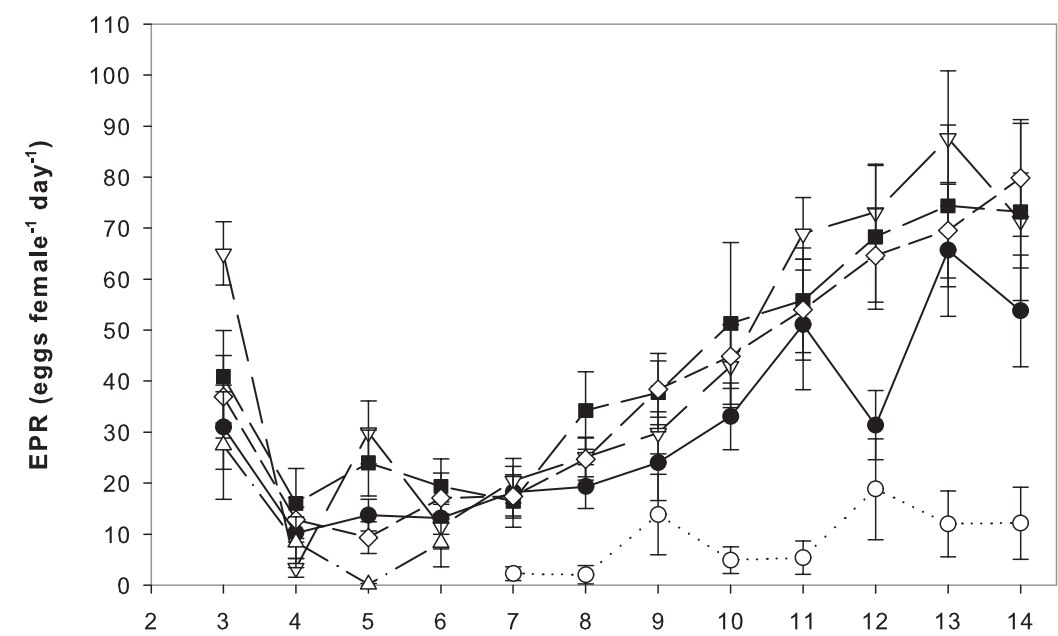

- B

$\nabla \quad$ C

- $E$

$\diamond \quad F$

O Ambient

$\triangle$ FSW

b)

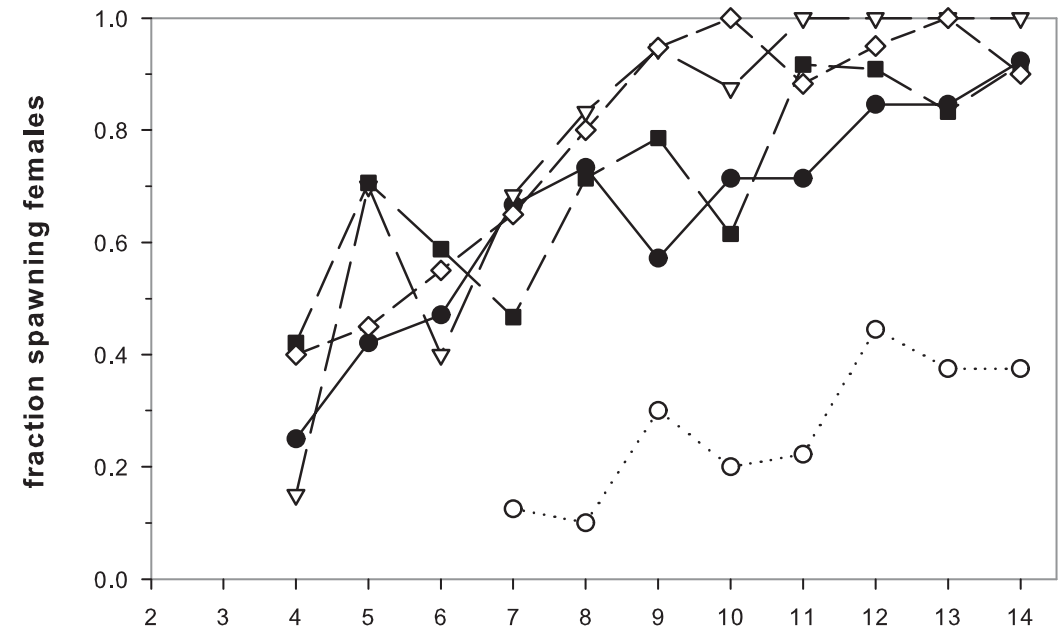

c)

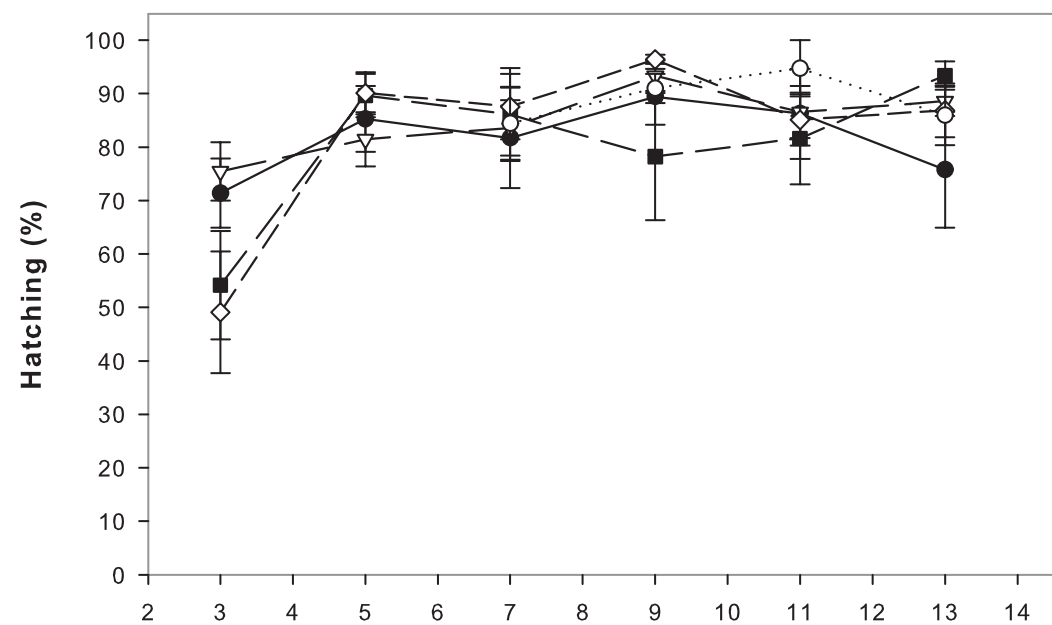

d)

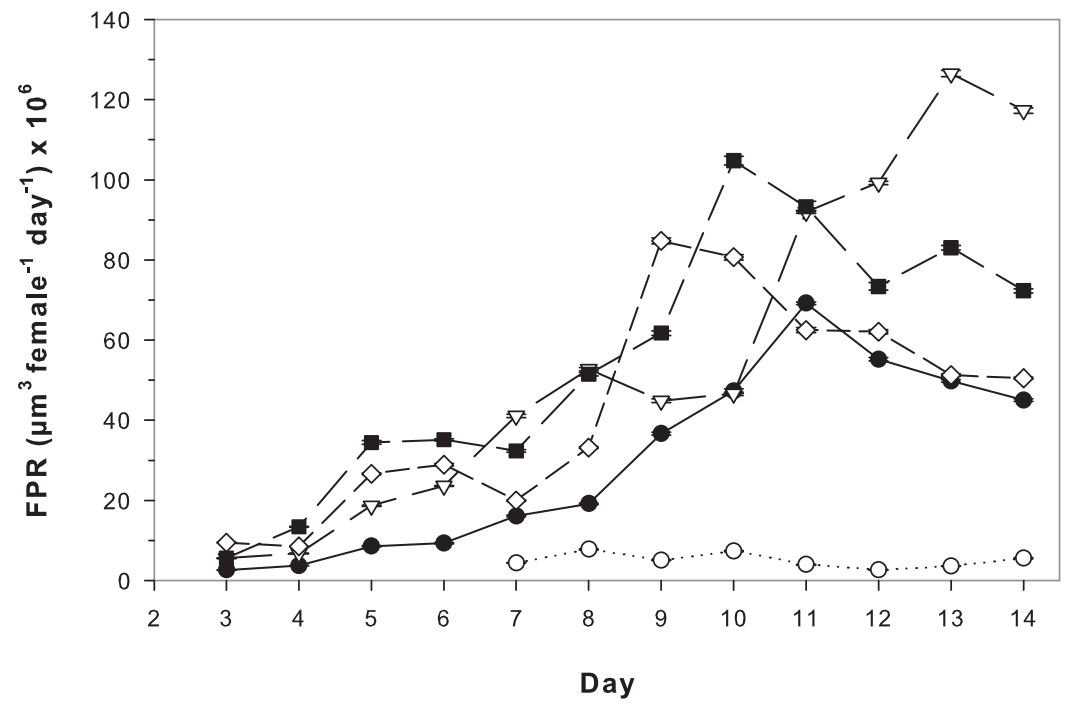


a)

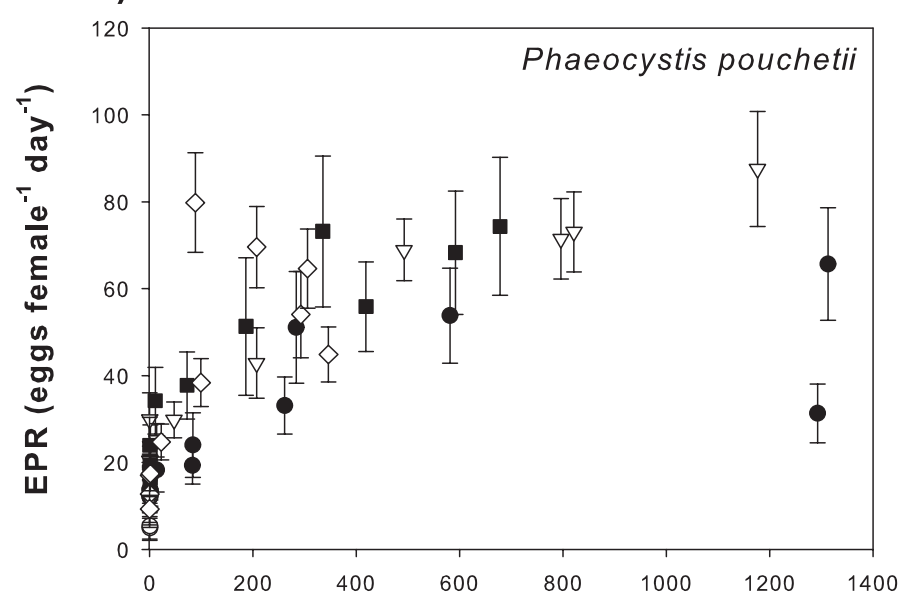

c)

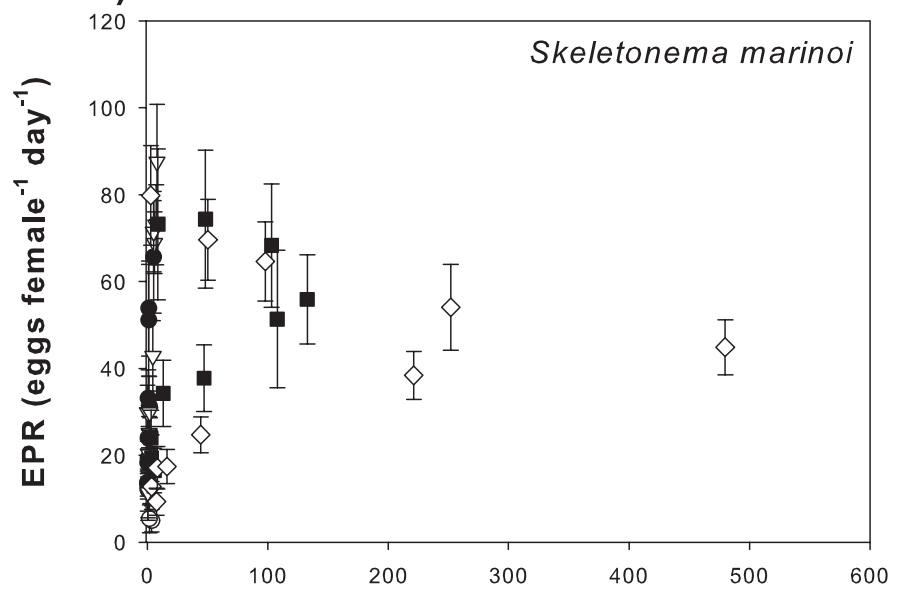

e)

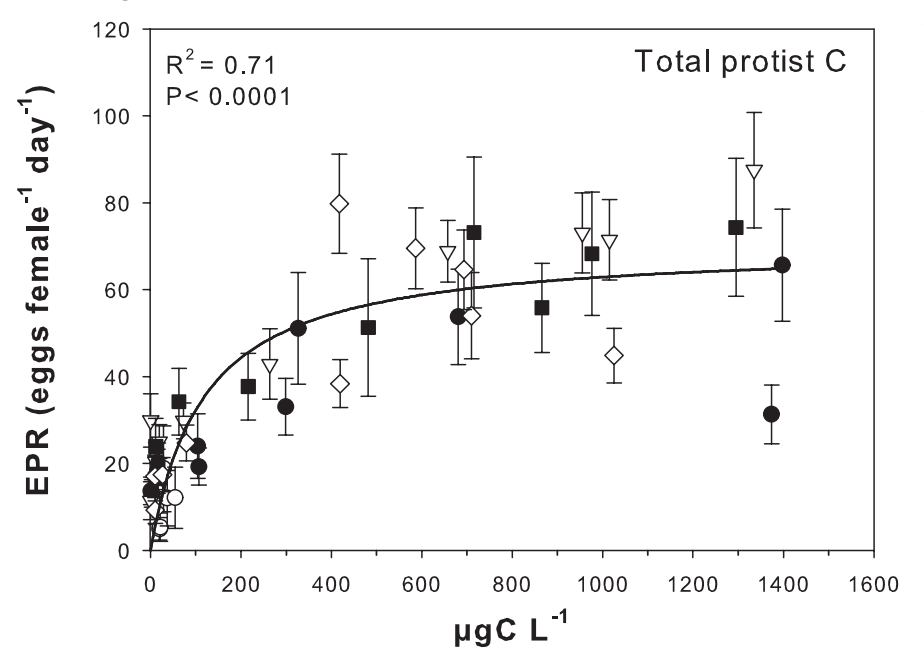

b)

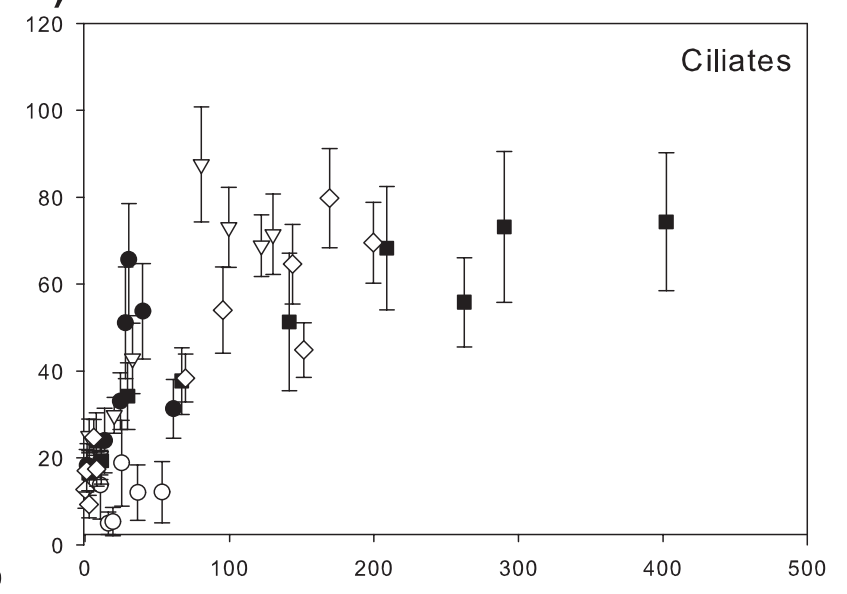

d)

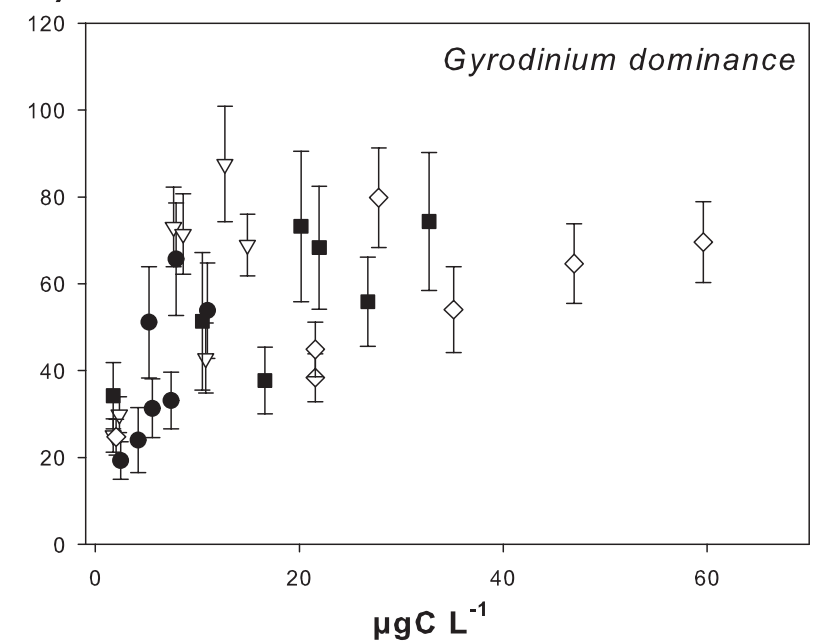

f)

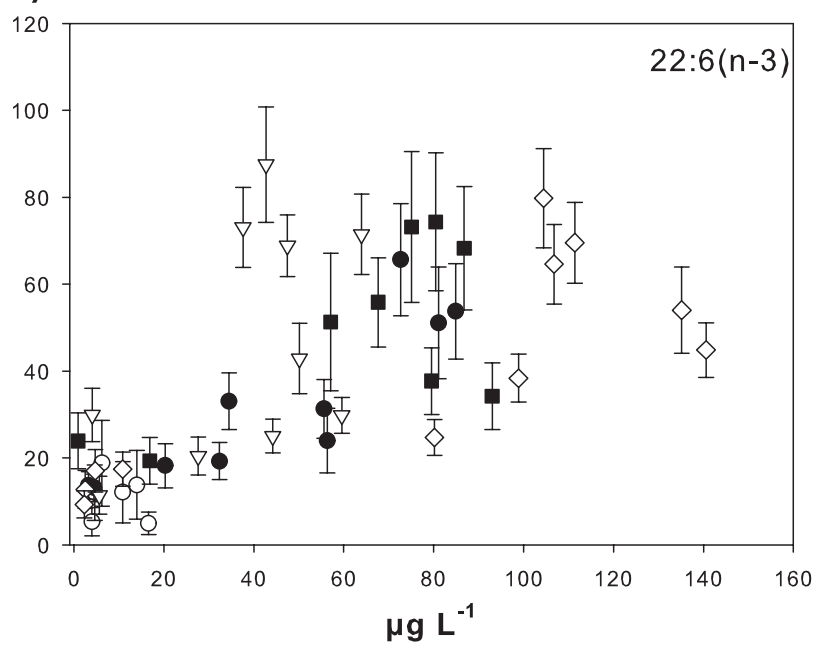


A) Skeletonema marinoi

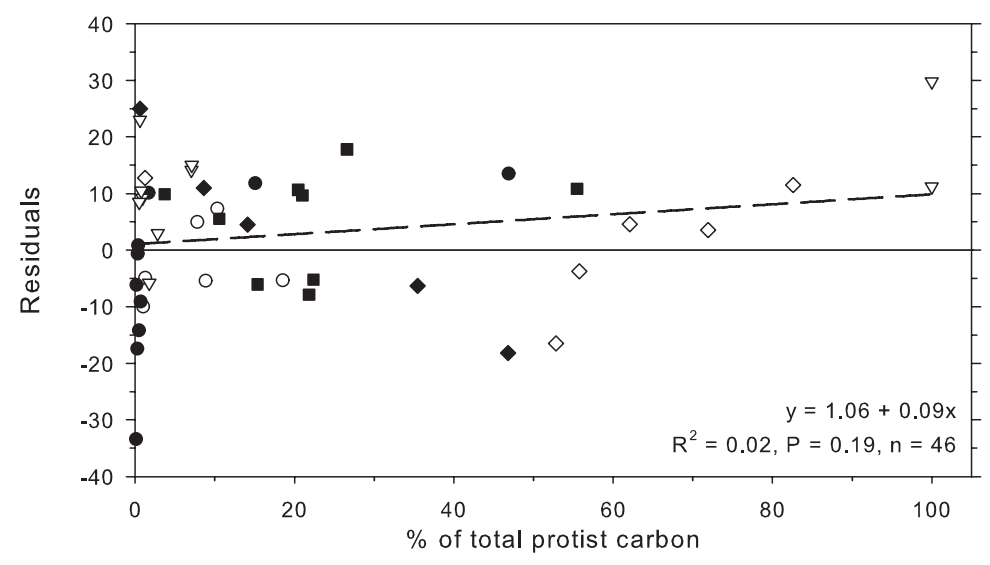

B) Phaeocystis pouchetii

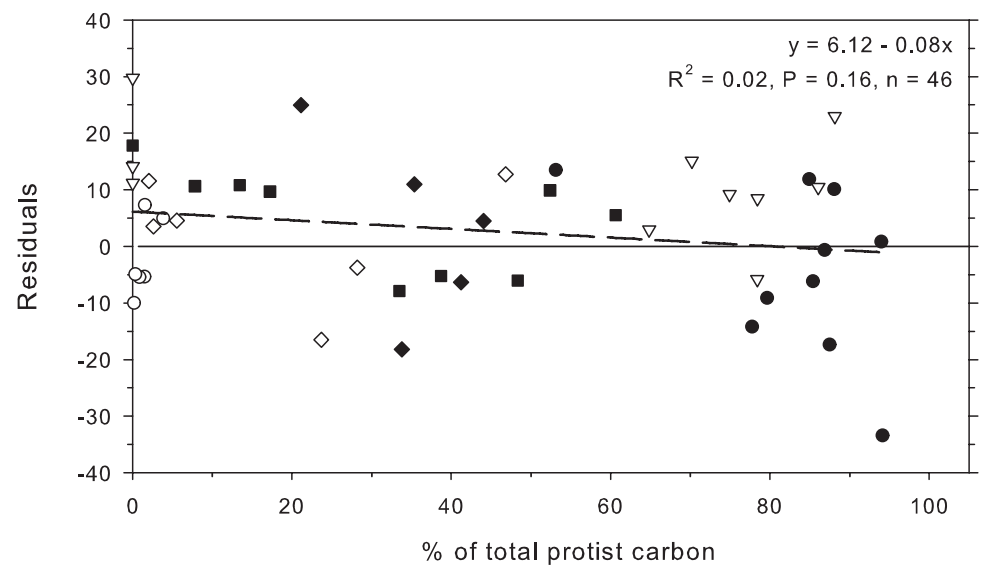

C) Particulate PUA

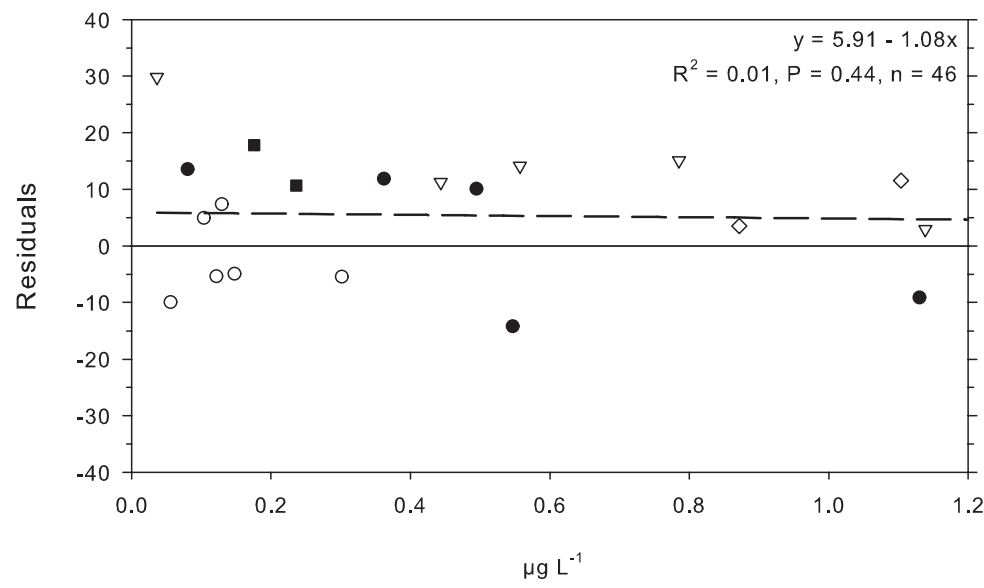

D) Dissolved PUA

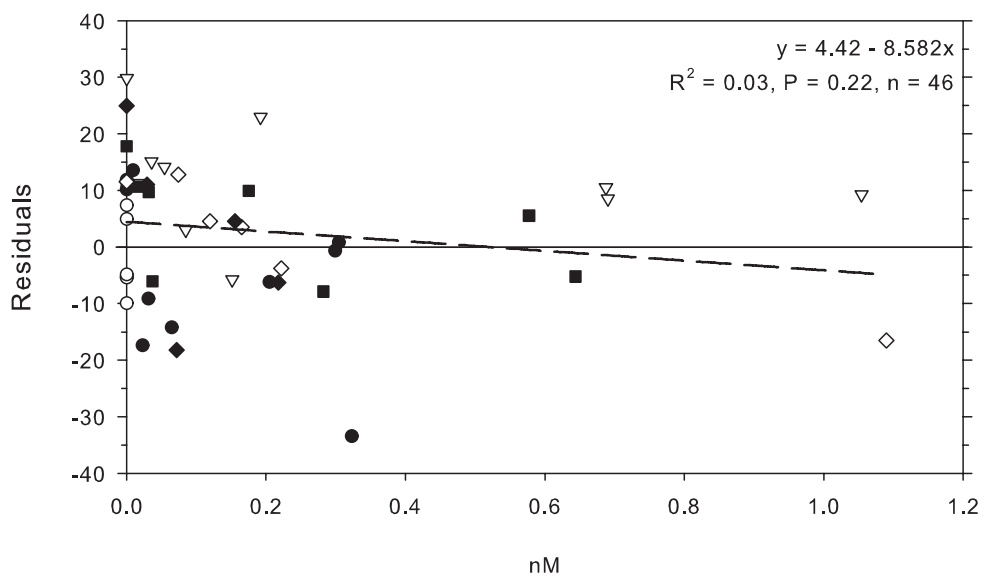


a)

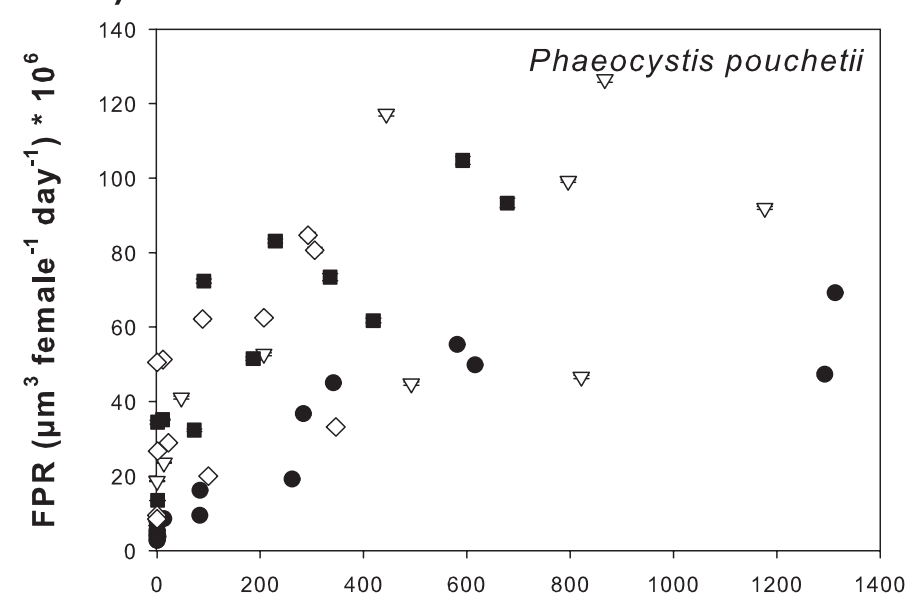

c)

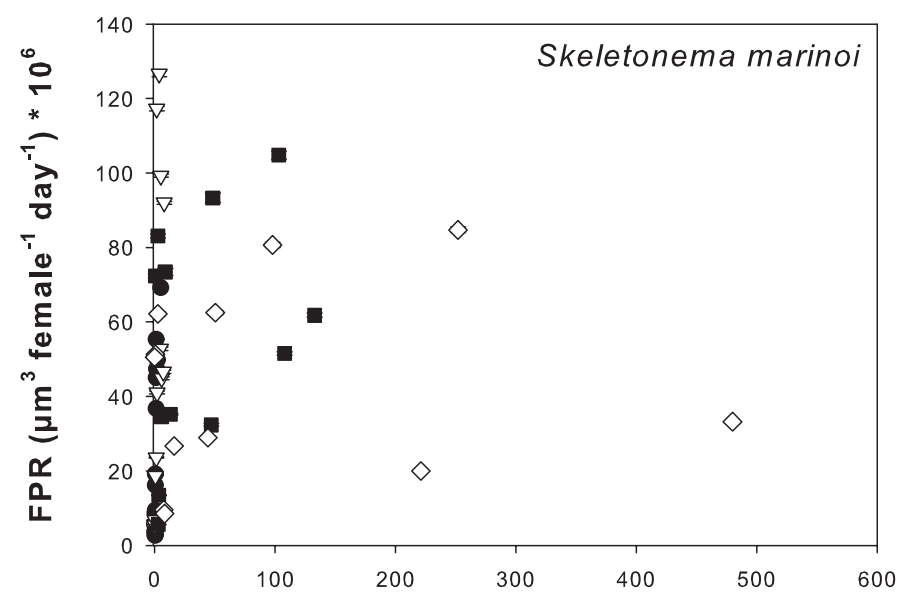

e)

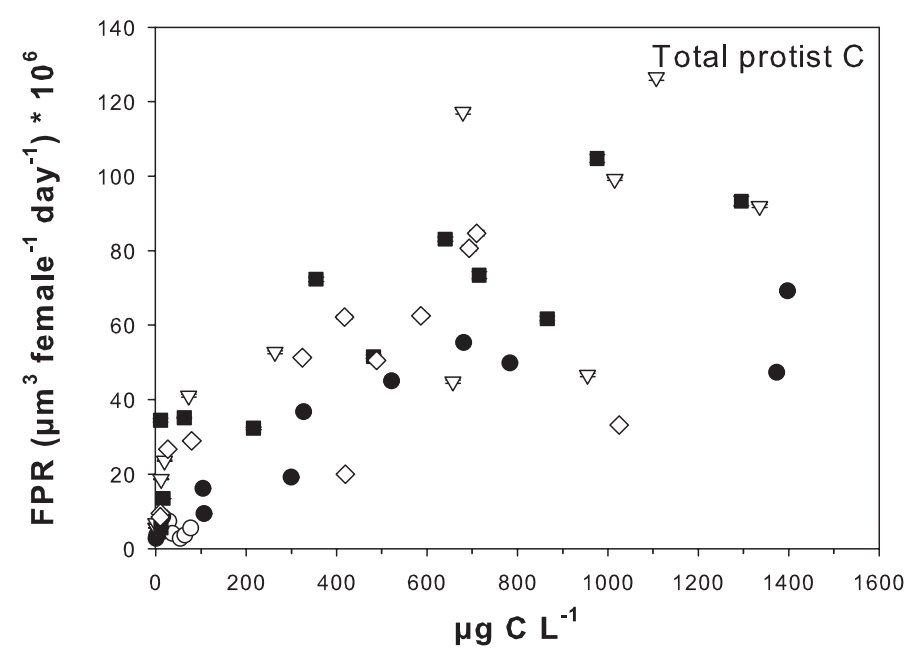

b)

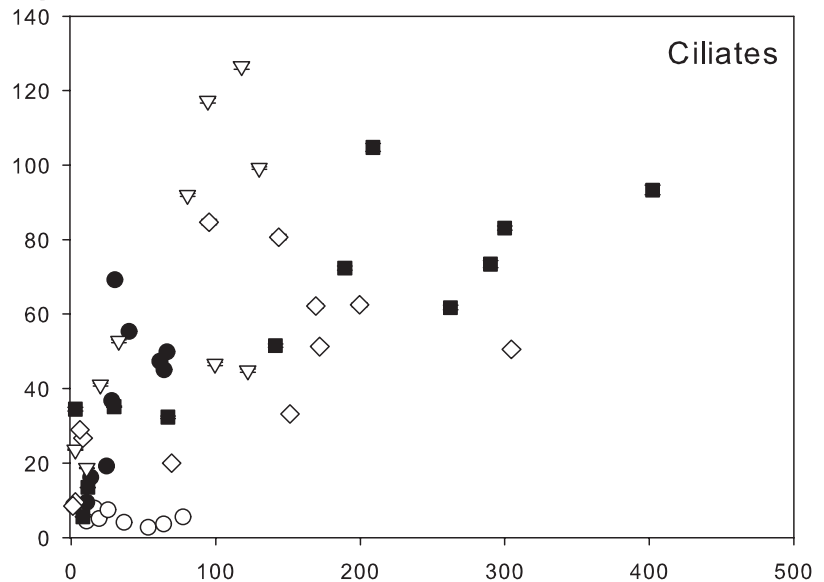

d)

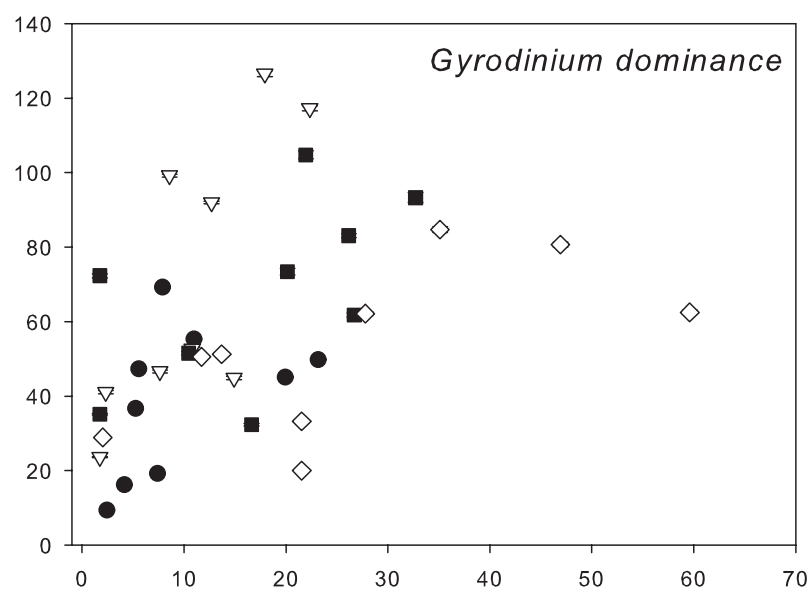

f)

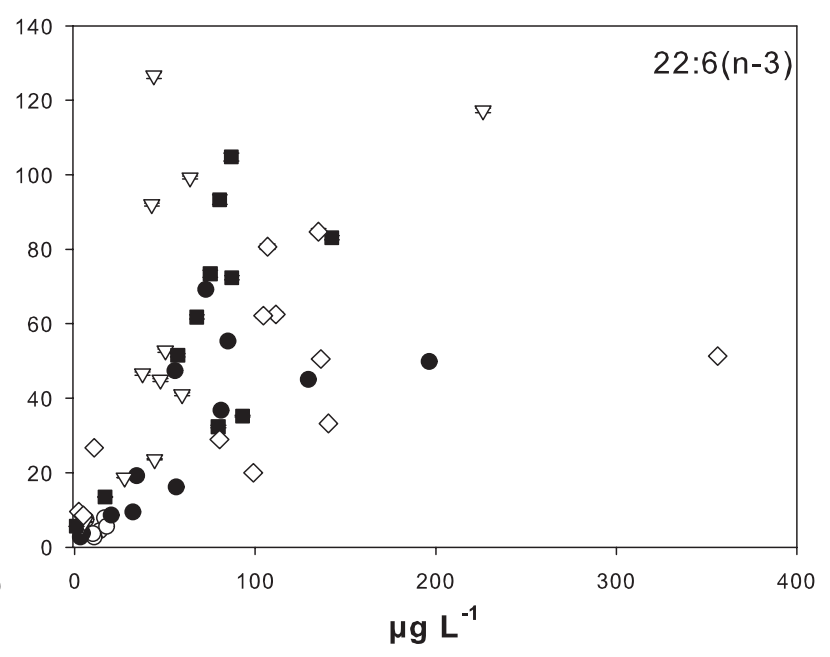




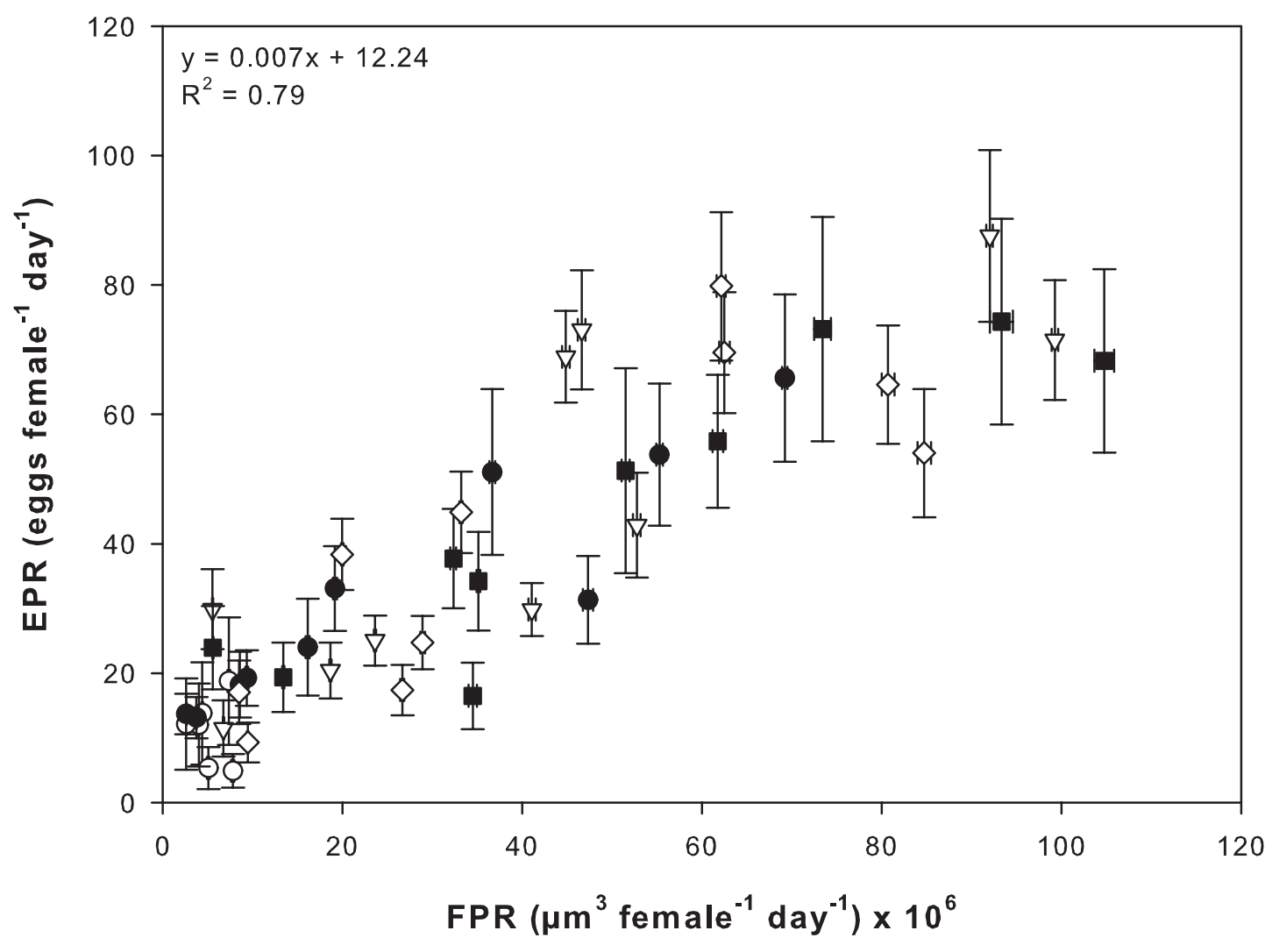

